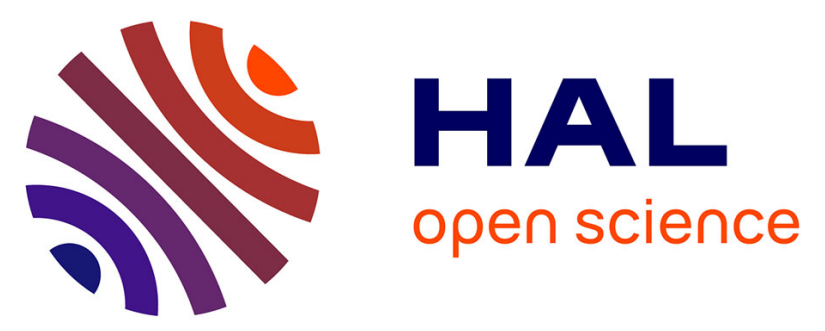

\title{
Contrasted tectonic styles for the Paleoproterozoic evolution of the North China Craton. Evidence for a 2.1 Ga thermal and tectonic event in the Fuping Massif
} Pierre Trap, Michel Faure, Wei Lin, Olivier Bruguier, Patrick Monié

\section{- To cite this version:}

Pierre Trap, Michel Faure, Wei Lin, Olivier Bruguier, Patrick Monié. Contrasted tectonic styles for the Paleoproterozoic evolution of the North China Craton. Evidence for a $2.1 \mathrm{Ga}$ thermal and tectonic event in the Fuping Massif. Journal of Structural Geology, 2008, 30 (9), pp.1109-1125. 10.1016/j.jsg.2008.05.001 . insu-00309553

\section{HAL Id: insu-00309553}

https://hal-insu.archives-ouvertes.fr/insu-00309553

Submitted on 6 Aug 2008

HAL is a multi-disciplinary open access archive for the deposit and dissemination of scientific research documents, whether they are published or not. The documents may come from teaching and research institutions in France or abroad, or from public or private research centers.
L'archive ouverte pluridisciplinaire HAL, est destinée au dépôt et à la diffusion de documents scientifiques de niveau recherche, publiés ou non, émanant des établissements d'enseignement et de recherche français ou étrangers, des laboratoires publics ou privés. 


\title{
Contrasted tectonic styles for the Paleoproterozoic evolution of the North China Craton. Evidence for a 2.1 Ga thermal and tectonic event in the Fuping Massif
}

\author{
P. Trap ${ }^{a}$, M. Faure ${ }^{a}$, W. Lin ${ }^{b}$, O. Bruguier ${ }^{c}$ and P. Moniéd \\ ${ }^{a}$ Institut des Sciences de la Terre d'Orléans, CNRS Université d'Orléans (UMR 6113), 45067 \\ Orléans Cedex 2, France \\ ${ }^{\mathrm{b}}$ State Key Laboratory of Lithospheric Evolution, Institute of Geology and Geophysics, \\ Chinese Academy of Sciences, Beijing 100029, China \\ ${ }^{\mathrm{c}}$ ISTEEM, Service Commun ICP-MS, cc 56, Université de Montpellier 2, 34095 Montpellier \\ Cedex 5, France \\ ${ }^{\mathrm{d}}$ Géosciences Montpellier, UMR CNRS 5243, Université Montpellier II, 34095 Montpellier \\ Cedex 5, France
}

\begin{abstract}
Structural analysis along with ${ }^{40} \mathrm{Ar}-{ }^{39} \mathrm{Ar}$ and $\mathrm{U}-\mathrm{Pb}$ datings in the Fuping massif provide new insight into the evolution of the eastern part of the Trans-North China Belt (North China Craton), from $2.7 \mathrm{Ga}$ to $1.8 \mathrm{Ga}$. D1 is responsible for the development of a dome-and-basin structure coeval with crustal melting giving rise to migmatite and Nanying gneissic granites at $2.1 \mathrm{Ga}$. This dome-and-basin architecture resulted from the interference between a N-S compression of a weak ductile crust and gravity-driven vertical flow, in a high thermal regime. The next events involved flat lying ductile thrusting (D2) and normal faulting (D3) dated at around $1880 \mathrm{Ma}$ and $1830 \mathrm{Ma}$, respectively. The D2 and D3 events belong to the Trans-North China Orogeny that results in the final amalgamation of the North China Craton. The D1 deformation is considered as evidence for an earlier orogen developed around $2.1 \mathrm{Ga}$ prior to the Trans-North China Orogeny. The change in the deformation style between the $2.1 \mathrm{Ga}$ and $1.8 \mathrm{Ga}$ could be viewed as a consequence of the cooling of the continental crust in the North China Craton.
\end{abstract}

Keywords: Trans-North China Belt; Paleoproterozoic geodynamics; Dome-and-basin structure; Ductile shearing; Syntectonic plutonism

\section{Introduction}

Vertical versus horizontal tectonics has been a common debate in recent years when discussing the crustal growth during Archean-Paleoproterozoic times (e.g., [Cawood et al., 2006], [Chardon et al., 1996], [Collins et al., 1998] and [Percival et al., 2001]). One of the most popular discriminating criteria for one or the other of these tectonic styles is the strain pattern recorded in a considered crustal segment. Horizontal tectonic style invokes a nearuniformitarian process of modern-style plate tectonics responsible for the development of flatlying foliation, coeval with ductile thrusts that allow superposition of crustal slices during crustal thickening, or normal faulting during extensional thinning. Conversely, vertical tectonics results in the development of large domains formed by juxtaposition of 1-10-km scale dome-and-basin structures, with steeply dipping foliation and lineation, and an upwelling and downwelling of infracrustal and supracrustal rocks, respectively (e.g. Chardon 
et al., 1996). This structural pattern is commonly interpreted as reflecting mantle convective instabilities rather than horizontal tectonics related to a subduction process. However, such a dome-and-basin structure could also be formed by several mechanisms involved in horizontal tectonics such as, for instance, compression of a weak and hot lithosphere (Cagnard et al., 2006). Indeed, if the lithospheric behaviour is controlled by far-field stresses, its thermal regime is a preponderant parameter for the temporal and spatial variations in lithosphere strength (McLaren et al., 2005). In addition, domes structures commonly formed in the anatectic core of young and partially exhumed orogens ([Teyssier and Whitney, 2002] and [Whitney et al., 2004]). Therefore, interpreting crustal scale strain patterns in term of tectonic style and behaviour of the continental lithosphere has to be considered with caution, in particular when dealing with paleoproterozoic time.

This study presents an example of an intra-continental dome-and-basin deformation zone with abundant crustal melting and anatectic plutonism, reworked by regional flat lying thrusting and low-angle ductile normal faulting. Both deformation styles reflect two distinct tectonic events separated in time by $200 \mathrm{Ma}$. The example comes from the Fuping Massif located in the central part of the Trans-North China Belt (TNCB) formed during the final amalgamation of the North China Craton, during Paleoproterozoic (Fig. 1A). In this study, the Fuping Massif is subdivided into three lithotectonic zones among which the principal one shows a dome-and-basin architecture that is the main focus of this paper. We also report new ${ }^{40} \mathrm{Ar}-$

${ }^{39}$ Ar muscovite and LA-ICP-MS zircon-monazite ages that comply with the relative timing inferred from our structural investigation and available geochronological data. Our results argue for a new tectonic event developed around $2.1 \mathrm{Ga}$.

\section{Lithological setting}

\subsection{The Fuping TTG gneiss}

The Fuping TTG gneiss consists of medium-grained tonalitic, trondhjemitic and granodioritic gneisses that resulted from the partial melting of mantle-derived basaltic rocks (Wang et al., 1991), in a magmatic arc environment (e.g. Guan, 2000). Recent geochronological studies based on SHRIMP U-Pb analyses on zircon support the conclusion that the emplacement of TTG magmas emplaced between $2520 \mathrm{Ma}$ and $2480 \mathrm{Ma}$, and marked the major period of crustal accretion of the Fuping Massif ([Guan et al., 2002] and [Zhao et al., 2002]) within a juvenile crust dated around $2.7 \mathrm{Ga}$ ([Bai, 1986], [Liu et al., 1985] and [Zhang et al., 1991]).

\subsection{The Wanzi supracrustal rocks}

The Wanzi supracrustal assemblage comprises felsic and pelitic gneiss, pelitic micaschists, calc-silicates, pure and impure marbles and amphibolites (e.g. Liu and Liang, 1997). The supracrustal rocks were deposited in the Neoarchean ([Wu et al., 1989], [Wu et al., 1991], [Wu and Zhong, 1998] and [Zhao et al., 2002]). However, some SHRIMP U-Pb zircon ages around 2.1 Ga led some authors to suggest that the Wanzi supracrustals were allochtonous to the Fuping TTG gneisses and deposited in the Paleoproterozoic (Guan et al., 2002). In agreement with Liu et al. (1985), we interpret the 2.1 Ga dates as the age of an HT metamorphism in relation with migmatization. 


\subsection{The Fuping migmatite}

Migmatization is a widespread phenomenon in the Fuping Massif ([Cheng et al., 2001], [Liu et al., 2002a] and [Wan et al., 2002]). Partially molten rocks developed at the expense of TTG gneiss that commonly remains as centimetre- to metre-scale enclaves. Due to the tectonic overprint, the migmatites are generally foliated and hence are often considered as a part of the 2.5 Ga TTG basement (Zhao et al., 2004). However, some metre-scale enclaves of metasedimentary rocks such as metapelites, metagreywackes and magnetite-bearing quartzites are locally observed within the foliated molten gneiss ([Liu et al., 2002a] and [Liu et al., 2004]) suggesting that (i) what is called TTG gneiss is in fact frequently migmatite and (ii) some parts of the supracrustal rocks experienced partial melting too. In addition, some small masses of S-type sillimanite-bearing granites derived from partial melting of supracrustal rocks (e.g. Wu et al., 1989). The wide area occupied by migmatites argues for intense partial melting of the crust in the Fuping Massif for which we distinguish a new entity called the "Fuping migmatite" that has never been recognized before.

Metatexites form the boundary between the Fuping TTG gneiss and the supracrustal rocks, where high strain zones commonly occur (see Section 4). At the first stage of the partial melting process, the leucosomes appear as isolated, thin elongated pockets, of pegmatoid or granitoid character, that commonly lie parallel to the rock fabrics (Fig. 2A). The matrix of the neosome shows the same texture, compositional layering and appearance as the Fuping gneisses or Wanzi supracrustal rocks, and thus both can be considered as the protolith or paleosome of the metatexites. When segregation is more efficient, leucosomes tend to coalesce, allowing the percolation of the melt fraction through the solid framework. The migmatite then adopts a stromatic structure made of a regular alternation of continuous, centimetre-scale granitic and paleosome layers (Fig. 2B).

In diatexite, the primary structure of the paleosome has been quite completely erased and the neosome (leucosome + melanosome) is prevalent (Sawyer, 1999). At the kilometre scale, the transition from metatexite to diatexite is gradational and is therefore hardly mappable. The pre-migmatitic rocks only occur as centimetre to 10-metre isolated fragments, which are commonly rounded, "floating" in the granitic matrix (Figs. 2C and 3B). These enclaves are biotite and amphibolite rich gneiss, garnet bearing amphibolites and granulites as well as Fuping TTG gneiss and Wanzi supracrustal rocks. Leucosomes patches occur in inter-boudin partitions and in the pressure shadows around restites (Fig. 2C insert). Various migmatitic structures were observed within the diatexite, such as ptygmatic folds, schöllen structure (Fig. 2C), agmatic, and schlieren structure (Menhert, 1968). Late cross cutting vein-like leucosomes are evidence for a conduit network that accommodated melt extraction and displacement (Fig. 2D). Although the scale of melt mobility cannot be constrained on the basis of field observations (Greenfield et al., 1996), melt mobility was sufficiently high to produce important transfers and accumulations of anatectic melt represented by the homogeneous Nanying gneissic granites.

\subsection{The anatectic Nanying gneissic granite}

Numerous intrusions of syntectonic homogeneous granitoids, named the Nanying gneissic granites, are evenly distributed within the Fuping Massif (Fig.1C). These plutons mainly occur in the core of the migmatitic dome and are intrusive (Zhao et al., 2002) within migmatites that commonly occur as metre to 10 -metre scale xenoliths (Fig. 3A). The Nanying gneissic granite also occurs as sheeted dykes (Fig. 3B and C) or as intrusions along the 
supracrustal and infracrustal boundary. In some localities, the Nanying gneissic granite contains abundant xenoliths of Wanzi supracrustal rocks (Liu and Liang, 1997). The Nanying gneissic granite is dominated by medium- to fine-grained, magnetite-bearing, foliated monzogranite with a minor amount of foliated granodiorite (Zhao et al., 2000a) and derived from partial melting of the Neoarchean Fuping TTG gneisses, with local contributions of the Wanzi supracrustal rocks ([Wu et al., 1989], [Liu et al., 2002a] and [Liu et al., 2004]). SHRIMP U-Pb zircon results reveal that the Nanying magmatism occurred from $2077 \pm 13$ to $2024 \pm 21 \mathrm{Ma}$ ([Guan et al., 2002] and [Zhao et al., 2002]).

\subsection{The Gantaohe sedimentary unit}

The Gantaohe Group is made of weakly metamorphosed phyllite, quartzite, sandstone, conglomerate and dolomite (Fig. 1, HBGMR, 1989). According to the geological maps of Hebei and Shanxi Provinces (HBGMR (Henan Bureau of Geology and Mineral Resources), 1989 and SBGMR (Shanxi Bureau of Geology and Mineral Resources), 1989) and to synthetic works (Yang et al., 1986), these terrigenous sediments are correlated with the Hutuo Group from Wutaishan, and gathered within the Hutuo Supergroup, interpreted as molassetype sediments deposited around 1850-1800 Ma ([Faure et al., 2007] and [Trap et al., 2007]).

\section{Structural outline}

\subsection{The bulk architecture of the Fuping Massif}

An interpretative kilometre-size structure of the Fuping Massif is drawn in Fig. 1D. The whole massif consists of well-foliated rocks deformed in a series of east-west trending domes and basins, named the Dome-and-Basin Domain. Two major flat-lying ductile shear zones cut this domain, the Lonquanguang Thrust in the west and northwest, and the Pingshan ductile normal fault in the southeast (Fig. 1D). The Fuping Massif is unconformably covered by Paleozoic sedimentary rocks, intruded by undeformed Mesozoic granites, and cut by Cenozoic high angle brittle faults but all these Phanerozoic events do not alter its bulk architecture acquired in Paleoproterozoic.

\subsection{The Dome-and-Basin Domain (D1 event)}

The trend of the regional foliation (S1) defines a dome-and-basin structure in which foliated migmatite coincides with E-W trending elliptical antiforms, the core of which is occupied by diatexite and anatectic Nanying gneissic granites (Fig. 1). The Wanzi supracrustal rocks and Fuping TTG gneiss crop out in the synformal structures and the lithological contacts are transposed into parallelism with the dome margins. The global dome-and-basin structure of the Fuping Massif is described in detail in Section 4.

\subsection{The Longquanguan Thrust (D2 event)}

The Longquanguan Thrust (LQGT) (Li and Qian, 1991) develops both in the western and northern parts of the Fuping Massif (Fig. 1). It constitutes a $\sim 2 \mathrm{~km}$ thick and $150 \mathrm{~km}$ long tectonic contact that may extend more to the south and to the north-east, hidden below the recent sedimentary cover (Fig. 1). The ductile deformation related to the LQG shear zone involves parts of the Fuping TTG gneisses, the Wanzi supracrustals and the Nanying granite ([Hao et al., 1995], [Li and Qian, 1991], [Wu et al., 1989] and [Trap et al., 2007]). Indeed, in 
the vicinity of the LQG Thrust, the Fuping rocks show near subhorizontal planar fabric (S2) that overprints the steeply dipping S1 foliation. When getting closer to the LQG Thrust, the $\mathrm{S} 1$ foliation is completely erased by the S2 foliation. Along the Longquanguan shear zone, S2 strikes between N05 and N50E in its southern part and between N60 and N80E in the northern part (Fig. 4, Fig. 6 and Fig. 7). It is gently dipping towards the NW with a plunge ranging from $20^{\circ}$ to $55^{\circ}$. The gneissic foliation commonly exhibits mylonitic to ultramylonitic fabrics, characterized by quartz ribbons with shape ratios up to 10:1 (Fig. 5A) that form centimetre to decimetre thick high strain zones. The S2 foliation holds a well-developed mineral and stretching lineation (L2) marked by elongated biotite clusters, preferentially oriented hornblende, calcite and epidote crystals. In the western part of the Fuping Massif, the lineation strikes N140-N160E, whereas it strikes N160-N170E in the northern part (Fig. 4, Fig. 6 and Fig. 7). Numerous intrafolial folds with axes parallel to the L2 lineation can also be observed. Along L2, abundant macroscopic and microscopic shear indicators such as asymmetrical pressure shadows around porphyroclasts, shear bands, and mica fish show a consistent top to the southeast kinematics, in agreement with previous studies (Fig. 5B and C; [Hao et al., 1995] and [Sun et al., 2004]). Therefore, considering both the S2 geometry and kinematics, and in agreement with Li et al. (2004) we argue that the LQG Shear Zone consists of a major thrust fault that allows the Wutaishan Massif to overthrust to the SE upon the Fuping Massif and therefore we prefer to use the term "Longquanguan Thrust" (LQGT) rather than Longquanguan Shear Zone ([Zhang et al., 2006a], [Zhang et al., 2006b] and [Zhao et al., 2004]). Finally some late D2 folds, overturned towards the SE, called F2, reworked both S1 and S2 (Fig. 4).

\subsection{The Pingshan detachment fault (D3 event)}

In the southeastern edge of the Fuping Massif, the Late Paleoproterozoic Gantaohe Group is separated from the underlying Fuping migmatite and supracrustal rocks by the Pingshan lowangle normal fault (Fig. 1). This fault is a 10-metre thick ductile shear zone. The foliation (denoted here as S3) strikes consistently NE-SW and dips at $30^{\circ}$ towards the southeast (Fig. 1 and Fig. 4). The intensity of the deformation increases progressively towards the shear zone where well-developed mylonitic fabrics are observed (Fig. 5D). A consistent N130E trending mineral lineation (L3) is marked by the elongation of quartz grains and feldspar porphyroclasts in sandstone, stretched decimetre-scale quartz pebbles in conglomerates. Along L3, clear macroscopic shear criteria such as $\sigma$-type porphyroclast systems, asymmetric pressure shadows around porphyroclasts, and shear bands provide a consistent top to the $\mathrm{SE}$ sense of shear (Fig. 5E). At the microscopic scale, sigmoidal quartz-feldpsar aggregates or white mica fishes show the same top to the SE shearing (Fig. 5F).

\section{Detailed structural analysis of the D1 event}

\subsection{D1 within the Fuping TTG gneiss, migmatite and supracrustal rocks}

\subsubsection{The S1 foliation}

The main structure in the Dome-and-Basin Domain is a penetrative S1 foliation that develops within the Fuping TTG gneisses, the migmatite, the supracrustal rocks and to a lesser extent in the Nanying gneissic granite (see Section 4.2). At map scale, the S1 foliation draws E-W trending elliptical domes and basins of 10-25 km length and 2-15 km width (Fig. 6, Fig. 7 and Fig. 8). At outcrop scale, the $\mathrm{S} 1$ foliation is defined by the metamorphic layering defined by the alternation of amphibole-biotite and quartz-feldspar rich layers. In diatexite, $\mathrm{S} 1$ is also 
defined by the compositionally homogeneous layers of quartzo-feldspathic leucosomes that represent crystallized melts (Fig. 9). The S1 foliation wraps around mafic restites (Fig. 3). In addition, some thin flattened and boudinaged mafic restites develop parallel to the foliation (Fig. 9A and B). Commonly, melt migrates from highly strained leucosome layers, parallel to the migmatitic foliation, towards centimetre- to decimetre-scale discordant vertical veins cutting the foliation (Fig. 9A and B). The melt migration from high to low strain zones, suggests that in diatexite, the foliation develops coevally with melting.

Although regionally E-W trending (Fig. 4), S1 strikes differently in the southwestern part and the northeastern part of the Fuping Massif. In the northeastern part (Fig. 6), the general trend of S1 varies from N100E to N130E and domes and basins exhibit a highly elongated shape. Throughout the dome, the dip of S1 changes regularly and defines sub-dome structures. S1 dips at $45-50^{\circ}$ along the dome limb whereas it is flat lying or dips more gently $\left(<30^{\circ}\right)$ at the top of the dome (Fig. 6 and Fig. 8). In this part of the Fuping Massif, no supracrustal rock is observed and the Fuping TTG gneiss, that has widely escaped migmatization, crops out in synforms with a moderately dipping attitude $\left(\sim 40^{\circ}\right)$. In the southwestern part of the Fuping Massif (Fig. 7), S1 strike is less regular as the general trend changes from N60E to N120E and domes are more rounded. The $\mathrm{S} 1$ foliation is steeply dipping along the dome flanks ( $\mathrm{S} 1>40^{\circ}$, commonly $\mathrm{S} 1>60^{\circ}$ ) and vertical in the synform axial zone. Wanzi supracrustal rocks occupy rim synclines that surround the migmatitic domes (Fig. 7 and Fig. 8).

Furthermore, the S1 pattern locally defines triangular arrangements that develop in order to accommodate the foliation geometry between elliptical domes (Fig. 7). In this southwestern location, the sub-domes structures outlined by the S1 trajectories are more developed than in the northeastern area (Fig. 6 and Fig. 7).

The gneissic migmatite grades from well-foliated stromatic migmatite, in the dome flanks, to moderately foliated diatexite within the dome core, where it is sometimes almost isotropic (Fig. 2). Along the dome limbs, at the boundary with supracrustal rocks or TTG gneiss, gneissic tectonites exhibit a well-pronounced foliation arguing for a high strain. Some shear zones have been previously described along the boundary between the Wanzi supracrustals and the migmatites ([Liu et al., 2002a] and [Tang and Liu, 1997]). Our observations confirm that the Fuping TTG gneiss and supracrustals experienced solid-state deformation, whereas at the same time, deformation in the migmatites, particularly in diatexite, is accommodated by a liquid (melt) with a lower viscosity and thus a softer rheology, through penetrative flow.

Along the dome limbs, S1 is disrupted by centimetre to metre-size folds (F1) with nearly horizontal axes (Fig. 4). These drags folds indicate an outer-part-side down displacement (Fig. 9D).

\subsubsection{Stretching direction}

In the migmatite, the mineral lineation (L1) is marked by elongated biotite aggregates, the preferred orientation of hornblende or sillimanite. However, in the field, deformed mafic restites are the most abundant and a clearer indicator of the stretching direction. Frequently, the competent layers of mafic material are boudinaged as isolated fragments while the surrounding material flows in towards the boudin necks (Fig. 10A). The filled voids between boudin fragments represent dilatant sites where the low strain allows melt to crystallize. Commonly, it is possible to define the $X \geq Y \geq Z$ axes of the strain ellipsoid. In most locations, mafic enclaves define planar and linear (S-L) fabrics (Fig. 10A). In some places, the elongated mafic lenses define a prolate shape as shown by the circular aspect in the $Y Z$ section 
(Fig. 10B). This L-type constrictional strain is generally observed at the eastern and western dome terminations.

At the scale of the entire Fuping Massif, the lineation pattern is scattered in the horizontal plane but shows a maximum in the E-W to ESE-WNW direction. Indeed, most of the L1 lineation measurements trend between N80E and N120E (Fig. 4). It is worth noting that along the dome limbs, a gently plunging lineation predominates and highly dipping or subvertical stretching lineation is absent. The high strain zones that develop along the E-W flanks of the domes are also associated with an E-W trending lineation (Tang and Liu, 1997). Shear sense is indicated by asymmetric pressure shadows around centimetre-scale restites (Fig. 9B), centimetre-scale sigmoidal leucosomes (Fig. 9C) and drag folds (Fig. 9D). Kinematic criteria indicate that the supracrustal rocks moved downward at the eastern and western closures of the domes whereas horizontal shearing took place along the northern and southern flanks. However, in those flanks, the sense of shear is unclear.

Therefore two dominant finite strain fabrics occur within the Dome-and-Basin Domain: (i) a planar-linear (S-L) fabric and (ii) a linear (L) fabric. The S-L fabric occurs at the top of the domes where foliation is flat lying, and defines a horizontal flattening. In the core and the flanks of the domes, flattening planes are nearly vertical, and correspond to a vertical flattening. In both cases, finite stretching ( $X$ axis) is $\mathrm{E}-\mathrm{W}$ trending and shallowly dipping to horizontal. The L-constrictional fabric lies at the eastern and western termination of the domes. There, the $X$ axis remains near E-W to ESE-WNW but plunges more steeply than within dome core and flanks.

\subsubsection{Coaxial vs non-coaxial regime}

Kinematic indicators of a non-coaxial regime occur principally along the dome closures. In the $X Z$ section, shear criteria such as $\sigma$-type porphyroclast systems and sigmoidal biotite along the downdip L1 show a consistent downward motion, i.e. top to the west and top to the east shearing at the $\mathrm{W}$ and $\mathrm{E}$ periclines, respectively. Along the dome flanks, the gently plunging lineation attests for a lateral shearing or longitudinal stretching. However, a non-coaxial regime is rarely observed at the outcrop scale. Conversely a coaxial flow can be documented by symmetric porphyroblast systems, and boudinaged enclaves. Combining the finite strain characterized by a N-S horizontal shortening together with an E W stretching, and the shear regime allows us to draw a simple structural pattern at the scale of a single dome (Fig. 11). A general model for the Dome-and-Basin Domain at the scale of the entire Fuping Massif is discussed in Section 7.1.1.

\subsection{D1 within the Nanying gneissic granite}

The Nanying gneissic granite forms $2.5-25 \mathrm{~km}$ long and 2-5 km wide homogeneous plutons. These elongated bodies, with shape ratios up to 6:1, stretch along an E-W trend in agreement with the regional pattern of S1 and L1 (Fig. 1). In Nanying gneissic granite, S1 is weak but conspicuous and consistently parallel to the well marked foliation developed within the surrounding rocks, leading authors to assume that the Nanying gneissic granite underwent the same deformation event ([Liu et al., 2004] and [Zhao et al., 2002]). The mineral preferred orientation that marks S1 becomes weaker towards the interior of the plutons, suggesting that deformation in the presence of melt is the predominant deformation mechanism within these granitoids. 
In the field, the magmatic layering is clearly outlined by thin, elongated pockets, $0.1-1$ metre long, consisting of biotite-free leucocratic material, which result from late magmatic quartzofeldspathic segregation (Fig. 12A). The planar fabric defined by these leucocratic pockets is in accordance with the $\mathrm{S} 1$ foliation in the surrounding rocks. The leucocratic pocket constitutive minerals, mainly feldspar and quartz, are not internally deformed. Such elongated microgranitoid enclaves, devoid of any plastic deformation of minerals, are strong evidence for magmatic flow (Vernon, 2000).

At the microscope scale, the $\mathrm{S} 1$ foliation in the Nanying gneissic granite is defined by the statistically shape-preferred orientation of biotite, hornblende, feldspar and weakly to moderately elongated quartz aggregates. No sign of significant solid-state deformation within biotite, such as shear bands, kinks or undulose extinction is observed. In quartz, only a few small grains show undulose extinction. Conversely, a range of microstructures provides evidence for deformation in the presence of melt. The best examples are intragranular fractures within feldspar megacrysts that are sealed by quartz which continues from inside to outside the phenocryst in the matrix (Fig. 12B) (Pawley and Collins, 2002). Similar fabrics have been described by Hibbard (1987) as "submagmatic microfractures," indicating that solid-state deformation occurred with migrating melt still present in the rock ([Bouchez et al., 1992], [Vernon, 1991] and [Vernon, 2000]). Microcline occurs mostly as filling the interstices between other minerals or replacing plagioclase in relation to fluid relocation and metasomatism during the late stages of magma crystallization (Marmo, 1971). Along microcline margins, myrmekite lobes or fringes developed (Fig. 12C). According to Vernon (2000), a subsolidus rheological state is a prerequisite for the replacement of K-feldspar by myrmekite. This feature is conspicuously observed in synkinematic granites (e.g., [Hibbard, 1987], [Marmo, 1971] and [Vernon, 2000]).

In summary, granite fabrics indicate that the Nanying granite represents syntectonic plutons, i.e. were gneissified during their emplacement that appears as coeval with the D1 deformation event, which is characterized by a N-S shortening and an E-W stretching. Due to buoyancy forces, regional stress field, density and viscosity contrasts of the anatectic magma with respect to the surrounding Fuping TTG gneiss and supracrustal rocks, the Nanying gneissic granite together with the diatexites form the core of the $\mathrm{E}-\mathrm{W}$ elongated domes.

\section{Metamorphic signature}

Rocks from the Fuping Massif experienced an amphibolite to granulite facies metamorphism except those from the Gantahoe Unit which are unmetamorphosed or weakly metamorphosed in greenschist facies only. Within the Fuping migmatite, some mafic granulites provide peak $P-T$ conditions of $0.8-1.0 \mathrm{GPa}$ and $750-830^{\circ} \mathrm{C}$ (Liu, 1996). Previous $P-T-t$ paths show that both mafic restites within migmatites and supracrustal rocks suffered the same final isobaric cooling and retrogressive conditions, with the latest stage computed at $700-750{ }^{\circ} \mathrm{C}$ and $6-$ 7 kbar (Fig. 13; [Liu and Liang, 1997] and [Zhao et al., 2000b]). The $P-T-t$ paths differ in the prograde evolution and for the peak metamorphism conditions (Fig. 13). Mafic enclaves within the migmatites preserve peak $P-T$ conditions of $850-950{ }^{\circ} \mathrm{C}$ and $8.5-9.5 \mathrm{kbar}$ but do not show petrographic evidence for an early prograde metamorphism due to subsequent annealing (Zhao et al., 2000b). These authors postulated that the mafic granulites represent mafic dykes emplaced at shallow depth which were buried to a deeper crustal level. Such mafic granulites could also represent mafic lower crustal material exhumed through a similar $P-T-t$ evolution, characterized by isothermal decompression followed by isobaric cooling (Fig. 13). Based on Nd-isotope data, model ages and field relationship, Liu et al. (2002b) 
suggest that the metabasites enclaves within the migmatites are not boudinaged mafic dykes but represent juvenile crustal material extracted from the mantle and underplated in the lower crust. Metapelites from the supracrustal sequence suffered near-isobaric heating from $680{ }^{\circ} \mathrm{C}$ and 8.0-9.0 kbar to $800^{\circ} \mathrm{C}$ and $8.0 \mathrm{kbar}$ before retrogression (Liu and Liang, 1997). There is no evidence of prograde metamorphism before the isobaric heating of the metapelites

(Fig. 13). However, pressures up to $8.0 \mathrm{kbar}$ reached by the sedimentary rocks argue for their initial burial.

A third $P-T-t$ path shows the metamorphic evolution of amphibolites from the adjacent OVU of the Wutaishan Massif (Fig. 13; Zhao et al., 1999). The thermal contrast and the difference in $P-T-t$ paths between Wutaishan amphibolites and the Fuping metabasites and metapelites imply that the central part of the Fuping Massif and the Wutaishan Massif are related to two different metamorphic events and that the Longquanguan Thrust is responsible for the juxtaposition of such distinct metamorphic domains.

\section{Timing of D1, D2 and D3 events}

\subsection{Structural relationship and relative timing}

The three deformations D1, D2, D3 defined by S1, S2, S3 and L1, L2, L3, planar and linear structural elements, have been recognized in the western, central, south-eastern areas of the Fuping Massif (Fig. 1 and Fig. 4). Regional mapping (Fig. 6 and Fig. 7) and overprinting relationships indicate that they can be assigned a temporal order. Our structural study demonstrates that undoubtedly D1 and D2 are two distinct deformational events with D2 being younger than D1. Similarly, D3 is younger than D1 since the dome-and-basin structure is reworked by the Pingshan fault. The relative timing between D2 and D3 is difficult to settle since the geometric superposition of these two deformation events is never observed in the same outcrop. However, the low-grade metamorphic conditions associated with D3 and the contrasted tectonic regimes, namely syn-amphibolite facies thrusting for D2 and syngreenschist to lower amphibolite facies normal faulting for D3, suggest that D2 is older than D3.

\subsection{Geochronological constraints}

\subsection{1. ${ }^{40} \mathrm{Ar}-{ }^{39} \mathrm{Ar}$ dating}

Previous studies in the adjacent Wutaishan Massif lead us to propose that the Hutuo Supergroup sedimentary rocks deposited after $1850 \mathrm{Ma}$ and before $1800 \mathrm{Ma}$ ([Faure et al., 2007] and [Trap et al., 2007]; see Section 2). In this consideration, the Pingshan fault might have functioned within this period. In order to assess the age of the Pingshan ductile fault, i.e., $\mathrm{D} 3$ deformation, we performed ${ }^{40} \mathrm{Ar}-{ }^{39} \mathrm{Ar}$ dating on a muscovite grain from a mylonite within the Pingshan fault. The sample (FP154) is a fine grained muscovite bearing gneiss belonging to the fault footwall, that exhibits a mylonitic fabric with well developed quartz ribbons and sigmoidal mica fishes and $\sigma$-type feldspar aggregates showing a top to the SE shearing (Fig. 5F).

The analytical procedure for laser probe dating is similar to that fully described by Dalrymple (1989) and consists of a continuous $6 \mathrm{~W}$ argon-ion laser connected to a MAP 215-50 mass spectrometer. Details concerning our experimental procedure are given in (Monié et al., 1994) and (Monié et al., 1997). The syn-kinematic muscovite grain $(0.5 \mathrm{~mm}$ in diameter) yields a 
plateau age of $1830 \pm 12 \mathrm{Ma}$ for $98 \%$ of ${ }^{39} \mathrm{Ar}$ released (Fig. 14A). Given the relatively lowtemperature conditions of deformation and the assumed closure temperature for argon diffusion in muscovite $\left(400{ }^{\circ} \mathrm{C}\right.$, Hames and Bowring, 1994), the age of $1830 \pm 12 \mathrm{Ma}$ is interpreted as the age of the D3 fabric of the ductile Pingshan normal faulting.

\subsection{2. $U-P b$ LA-ICP-MS dating}

To support structural results, three samples of migmatite were analysed using LA-ICP-MS dating. Sample FP133 is a leucocratic segregate from a stromatic migmatite situated in the southwestern edge of the Fuping Massif, in the footwall of the Longquanguan Thrust $\left(\mathrm{N} 38^{\circ} 15.577^{\prime} / \mathrm{E} 113^{\circ} 30,340^{\prime}\right)$. Sample FP135 is a diatexite sampled near a Nanying gneissic granite pluton within a migmatitic dome, east of Diantou (N38 $\left.19.565^{\prime} / \mathrm{E} 113^{\circ} 37.015^{\prime}\right)$. FP205 is a coarse grained $(1-6 \mathrm{~mm})$ migmatite leucosome sampled from a dilatant site between stretched mafic restites, near Liangang village $\left(\mathrm{N} 39^{\circ} 15.794^{\prime} / \mathrm{E} 115^{\circ} 03,7^{\prime} 7^{\prime}\right)$.

Zircon grains were mounted in epoxy resin with chips of a standard material (G91500; Wiedenbeck et al., 1995). Analyses were performed using a VG Plasmaquad II turbo ICP-MS coupled to a Geolas (Microlas) automated platform housing a $193 \mathrm{~nm}$ Compex 102 laser from LambdaPhysik. Details of the analytical procedure are described in Bruguier et al. (2001). Age calculations were done using the Isoplot program (Ludwig, 2000) and are quoted at the $2 \sigma$ level. Results are shown as a Concordia plot in Fig. 14. Zircons have euhedral to subeuhedral shapes, some of them yielding domains with faint oscillatory or convolute zoning but most grains lack clear zoning features and yield rounding of their terminations. These observations are interpreted as indicating that they originally crystallized from a melt, but were subsequently subject to a metamorphic event that could have been responsible for blurring of the primary structure and rounding of their terminations.

In the $\mathrm{Th} / \mathrm{U}$ versus apparent $\left({ }^{207} \mathrm{~Pb} /{ }^{206} \mathrm{~Pb}\right)$ age diagram of Fig. $14 \mathrm{~B}$, zircons from sample FP133 yield a clear tendency to younger ages with decreasing $\mathrm{Th} / \mathrm{U}$ ratios whereas the oldest ages are associated with the highest $\mathrm{Th} / \mathrm{U}$ ratio. Our best estimate for the age of zircon recrystallization in sample FP133 is thus given by the ${ }^{207} \mathrm{~Pb} /{ }^{206} \mathrm{~Pb}$ weighted mean of the youngest concordant analyses, which yields an age of $1847 \pm 7 \mathrm{Ma}$ (Fig. 14C). Moreover, two analyses yield an intercept at $1875 \pm 13 \mathrm{Ma}$ (Fig. 14C). Although this age is calculated only starting from two analyses it should be considered since it is well consistent with numerous ages documented around 1870-1880 Ma reported in the area (Fig. 15, see Section 6.2.3). A batch of analyses yields older ages, close to $2.5 \mathrm{Ga}$, and 4 grains with a low discordance degree provide $\mathrm{a}^{207} \mathrm{~Pb} /{ }^{206} \mathrm{~Pb}$ weighted mean age of $2481 \pm 7 \mathrm{Ma}$ (Fig. 14C). Finally a concordant analysis defines an inherited component as old as $2562 \pm 12 \mathrm{Ma}$. Monazite grains from the same sample FP133 yield a well-defined intercept age at $1837 \pm 6 \mathrm{Ma}$ (Fig. 14D).

Alike for sample FP133, zircons from sample FP135 yield a tendency to younger ages with decreasing $\mathrm{Th} / \mathrm{U}$ ratios whereas the oldest ages are associated with the highest $\mathrm{Th} / \mathrm{U}$ ratio (Fig. 14B). Almost all analyses are quite discordant except for older ages among which 4 analyses allows us to calculate a mean age at $2456 \pm 11 \mathrm{Ma}$ (Fig. 14E). Younger ages are too discordant to calculate a reliable age.

Sample FP205 yield a restricted distribution, all grains but two having $\mathrm{Th} / \mathrm{U}$ ratios of less than 0.1 (Fig. 14B). Zircon grain analyses from sample FP205 also scatter in a fan-like domain, which reflect inheritance and various degrees of $\mathrm{Pb}$ losses. The discordance degree is more important for zircons from this sample than from sample FP133. This is likely to be related to 
the higher $\mathrm{U}$ content of the grains ( $>1000 \mathrm{ppm}$ ) in sample FP205, which enhanced $\mathrm{Pb}$ losses. Given the discordance and scattering of the data point it is difficult to calculate an age, however it is noteworthy that two analyses plot close to the concordia and have ${ }^{207} \mathrm{~Pb}-{ }^{206} \mathrm{~Pb}$ ages of $1846 \mathrm{Ma}$ and $1865 \mathrm{Ma}$. The younger age together with three other discordant ones allows calculating a weighted mean age of $1842 \pm 12 \mathrm{Ma}$ (Fig. 14F), similar to the age of zircon recrystallization in sample FP133 at $1847 \pm 7 \mathrm{Ma}$. Moreover, no $\sim 2.5 \mathrm{Ga}$ ages are reported but a clear inherited component yields an age around $2100 \mathrm{Ma}$, with a near concordant age at $2099 \pm 5 \mathrm{Ma}$. This is in agreement with the age frequency histogram (Fig. 14F insert). Indeed it shows that the distribution does not follow a Gaussian law, but two main groups of ages appear, one around $1850 \mathrm{Ma}$ and a second close to $2050 \mathrm{Ma}$, with some mixing that probably occurs between these two ages. Unfortunately the degree of discordance and the small amount of analyses do not allow us to calculate a reliable age around 2.0$2.1 \mathrm{Ga}$.

\subsubsection{Interpretation of $U-P b$ LA-ICP-MS zircon ages}

In sample FP133, five analyses yield a mean age at $2481 \pm 7$ Ma while a concordant analysis defines an inherited component at $2562 \pm 12 \mathrm{Ma}$. In sample FP135, a mean age has been calculated at $2456 \pm 11 \mathrm{Ma}$ while a near concordant analysis has an age at $2523 \pm 3 \mathrm{Ma}$. Such Late Archean to Early Paleoproterozoic ages have been widely reported in the Fuping Massif ([Liu et al., 2000] and [Zhao et al., 2002]). In particular, the ages of $2481 \pm 7 \mathrm{Ma}$ and $2523 \pm 3 \mathrm{Ma}$ are very close to the ages of $2486 \pm 8 \mathrm{Ma}$ and $2523 \pm 14 \mathrm{Ma}$ reported from TTG gneiss (Zhao et al., 2002). In agreement with Zhao et al. (2002) these old ages ranging from 2520 to $2480 \mathrm{Ma}$ represent the timing of emplacement of the TTG magma. The inherited zircon cores and xenocrysts documented around $2.7 \mathrm{Ga}$ (Guan et al., 2002) argue that the TTG magma intrudes an old continental nucleus ([Bai and Dai, 1998], [Wu et al., 1991] and [Wu and Zhong, 1998]). The mean age of $2456 \pm 11$ Ma reported in the sample FP135 is a little bit younger, but similar within error, to the SHRIMP U-Pb age of $2474 \pm 20 \mathrm{Ma}$, reported by Liu et al. (1985) and interpreted by the authors as a metamorphic age.

Such old ages are not reported in sample FP205 for which the older ones lie around $2100 \mathrm{Ma}$ and represent the timing of melt crystallization. Unfortunately, the discordance degrees as well as the weak amount of single ages do not allow us to calculate a mean age. However, the 2.0-2.1 event is well documented in the literature (Fig. 15 and references therein). A conventional multi-fraction zircon U-Pb age of 2025+46/-36 Ma was documented for a paragneiss of the Wanzi supracrustals, and was interpreted as dating the timing of metamorphism (Liu et al., 1985). SHRIMP U-Pb zircon dating results reveal that the anatectic Nanying granites were emplaced between $2077 \pm 13$ and $2024 \pm 21 \mathrm{Ma}$ ([Guan et al., 2002] and [Zhao et al., 2002]). Sun and Guan (2001) propose that a magmatic event took place at ca. 2.05 Ga while Zhao et al. (2002) report near concordant ages at $2100 \mathrm{Ma}$ from what they considered as the Fuping TTG gneiss but that we redefined here as migmatite. Guan et al. (2002) obtained a SHRIMP U-Pb age of $2097 \pm 46 \mathrm{Ma}$ from the fine-grained paragneiss of the Wanzi supracrustals. Furthermore, zircons from a Wanzi supracrustal sillimanite leptynite yielded two SHRIMP ages of $2507 \pm 14 \mathrm{Ma}$ and $2109 \pm 5 \mathrm{Ma}$ (Zhao et al., 2002). Although these authors interpret the second age as the maximum deposition age, we suggest that it might correspond to that of the regional HT metamorphism and associated migmatization.

Our structural study attests that the Fuping TTG gneisses, Wanzi supracrustal rocks, Fuping migmatite and the anatectic Nanying gneissic granite experienced the same D1 deformation 
coeval with conspicuous partial melting and anatectic granite emplacement. In agreement with our structural and geochronological results, and especially the geochronological data set from the literature, we suggest that the age of the D1 deformation can be estimated between $2100 \mathrm{Ma}$ and $2000 \mathrm{Ma}$.

The other ages reported from our study range in the period 1880-1820 Ma, which is thought to represent the timing of the main metamorphic event related to the collision and building of the TNCB (e.g. Kröner et al., 2005). However, recent studies pointed to a polyphase deformation history within the 1880-1820 period ([Faure et al., 2007] and [Trap et al., 2007]). This was confirmed by recent geochronological studies performed on the TNCB, that document two dominant geochronological periods, at 1870-1890 Ma and 1830-1850 Ma (Fig. 15, [Liu et al., 2006] and [Trap et al., 2007]).

From sample FP133, a mean age has been calculated at $1875 \pm 13$ Ma which is very close to that of $1875 \pm 43 \mathrm{Ma}$ (Zhao et al., 2002) from a trondhjemitic gneiss. Sample FP133 comes from the footwall of the Longquanguan Thrust along which recent chemical $\mathrm{U}-\mathrm{Th}-\mathrm{Pb}$ dating of monazite by electron microprobe of an orthogneiss yields an age of $1877 \pm 11 \mathrm{Ma}$ interpreted as the age of the ductile shearing (Zhao et al., 2006). Indeed, the Longquanguan Thrust, together with several other thrust faults located more to the west, are responsible for nappe stacking, resulting in crustal thickening and amphibolite facies metamorphism which is well constrained between 1870 and $1890 \mathrm{Ma}$ in the TNCB ([Faure et al., 2007] and [Trap et al., 2007]). Therefore, the D2 event, related to the activity of the LQG Thrust and responsible for nappe stacking within the TNCB, is estimated at around 1870-1890 Ma.

Sample FP133 yields an age at $1847 \pm 13 \mathrm{Ma}$ which is in agreement with that of $1841 \pm 5 \mathrm{Ma}$ from the monazites of the same rock as well as the age of $1842 \pm 12 \mathrm{Ma}$ from the sample FP205. These ages are quite similar to the muscovite ${ }^{40} \mathrm{Ar}-{ }^{39} \mathrm{Ar}$ age of $1830 \pm 12 \mathrm{Ma}$ associated with the D3 event. Moreover, younger ages of $1826 \pm 12 \mathrm{Ma}$ and $1850 \pm 10 \mathrm{Ma}$ have been measured from grain overgrowths within TTG and Nanying granite, respectively (Zhao et al., 2002). Recently Zhang et al. (2006a) give ages of $1843 \pm 12 \mathrm{Ma}$ and $1844 \pm 18 \mathrm{Ma}$ from SHRIMP zircon analysis of leucocratic dykes. Therefore, we suggest that the youngest ages ranging between 1820 and $1850 \mathrm{Ma}$ within the Fuping massif are related to a late-orogenic event (D3) different from the D2 event responsible for nappe stacking ca. 30 $50 \mathrm{Ma}$ before.

Fig. 15 is a synthesis of geochronological data. Four age groups are pointed out: (i) $2700 \mathrm{Ma}$ inherited ages, (ii) Neoarchean ages (ca. $2500 \mathrm{Ma}$ ) corresponding to the emplacement of TTG magma, (iii) the ca. $2100 \mathrm{Ma}$ ages that correspond to a period of intense crustal melting coeval with the D1 event and (iv) the 1900-1800 Ma ages related to the TransNorth China Orogeny.

\section{Discussion}

\subsection{Tectonic setting for the domes and basins emplacement at $2.1 \mathrm{Ga}$}

The regional-scale dome-and-basin architecture of the Fuping Massif has been recently described as an interference pattern due to the superposition of two deformations responsible for development of folds with different axial directions ([Zhang et al., 2006a] and [Zhang et al., 2006b]). However, such fold interference may produce lineation patterns expected from 
a doubly folded surface, in particular without any variation of the finite strain patterns relative to the position in the dome (Whitney et al., 2004). Thus a cross-folding model is not in agreement with structural features described above for the Fuping Massif. In the Fuping Massif, a metamorphic core complex setting is also precluded since large scale detachment faults that would accommodate extensional doming is lacking, and no unidirectional mineral lineation or consistent sense of shear have been reported across the whole massif.

Dome-and-basin domains are widespread in Precambrian terrains and are commonly pointed out as an argument against uniformitarianism (e.g. Choukroune et al., 1995). These domeand-basin domains are considered to result from diapirism triggered by gravitational instabilities. The typical structural feature is a steeply dipping mineral lineation that converges towards a zone of intense vertical constrictional strain (Collins et al., 1998). Kinematic indicators suggest a systematic downward displacement of the supracrustal rocks relative to infracrustal ones ([Bouhallier et al., 1993] and [Choukroune et al., 1995]). However, such regions deformed by body force often experienced an additional episode of regional deformation which was the result of application of boundary forces. As a consequence, the finite strain pattern due to diapirism is partly reworked or superimposed by a deformation related to a regional stress field, as described in the Indian and Man shields (e.g. [Choukroune et al., 1993], [Choukroune et al., 1995] and [Bouhallier et al., 1993]). The absence of steeply dipping lineation all around the domes suggests that a gravity-dominated process alone such as sagduction cannot be advocated. Even if a weak radial scattering can be observed, the L1 stretching lineation within Fuping domes is dominantly E-W to ESE-WNW trending (Fig. 4). The constant orientation of the stretching lineation in a magmatic gneiss dome has been attributed to the influence of a regional strain field (e.g., Whitney et al., 2004), which is, in the case of the Fuping Massif, characterized by a N-S trending shortening and an $\mathrm{E}-\mathrm{W}$ trending stretching. However, this regional strain field alone cannot explain all the structural features observed in the Fuping domes and some evidence suggests a role of the body forces or diapirism. Numerous petrological and structural indications show that deformation was coeval with migmatization. Stretched restites and preferred accumulation of melt in dilatants sites comply with the interpretation that the boudinaged migmatitic foliation in the Fuping Massif developed during melting. For instance, the $\mathrm{S} 1$ foliation of the Fuping diatexite wraps around mafic restites (Fig. 3) suggesting interplay between melt flow and deformation controlled by the regional stress field (Sawyer, 1999). Diatexites preferentially exposed in the core of the domes and the high strain domains developed along the dome flanks, suggest that migmatite behaved as a magma that rose by buoyant upwelling towards the low strain domain, through deformation of the surrounding metatexites (Vanderhaeghe, 2001). At the outcrop scale, wayup criteria such as vertical leucocratic veins attest for an upward motion of melt during deformation (Burg and Vanderhaeghe, 1993). This is also in agreement with the ubiquitous existence of the diatexite and anatectic granites in the dome cores as observed in other migmatitic domes formed by diapirism (Whitney et al., 2004) and the conspicuous preservation of syn-magmatic textures in most of the Nanying plutons. In the southwestern part of the Fuping area the supracrustal rocks extend around the migmatitic dome in a concentric manner forming circular depression, known as rim synclines. Such rim synclines commonly encircle domal uplift and are also well documented in salt diapiric systems (e.g. Scheck et al., 2003). In addition, numerous sub-domes structures, horizontal and vertical flattening in the top and core of the domes, respectively, as well as the strong strain gradient from core to flanks of domes are further evidence for diapirism ([Choukroune et al., 1995], [Teyssier and Whitney, 2002] and [Whitney et al., 2004]). In the Fuping massif, the steeply dipping lineation that characterize vertical movement is lacking, but this fact does not preclude any vertical component of movement. The Gundlupet area within the Dharwar 
craton, India, shows a lot of similarities with the Fuping area. There, regional deformation is nearly coaxial, with a horizontal regional stretching lineation, and without any evidence of relative displacement between supra- and infracrustal rocks ([Bouhallier et al., 1995] and [Choukroune et al., 1995]). Nevertheless, Choukroune et al. (1995) argue for a diapiric origin of the Gunlupet dome-and-basin area due to numerous structural features such as parallelism of foliation trajectories between supra- and infracrustal rocks, strain increase at these contacts, location of triple junctions, and heterogeneous distribution of strain regime. The direction of maximum stretching in migmatitic domes tends to follow that of regional stretching because the latter constitutes a preferred direction of expansion for the migmatitic and magmatic rocks. In addition, the location of the constrictive deformation restricted to the termination of rising elliptical domes within the Fuping Massif is a typical feature encountered in dome systems formed through a competition between deformation due to regional strain field and deformation induced by diapirism (Choukroune et al., 1995). Finally, an isothermal decompression before isobaric cooling $P-T-t$ path is recorded by granulite enclaves enclosed in diatexites whereas adjacent supracrustal rocks record a clockwise $P-T$ path with no significant isothermal decompression (Fig. 13; [Liu and Liang, 1997] and [Zhao et al., $2000 \mathrm{~b}]$ ). Among a number of tectonic processes, diapirism typically leads to isothermal decompression of the deep crust (Teyssier and Whitney, 2002). The difference in decompression paths between the granulite restites within migmatitic dome and the supracrustal rocks within basins attests for a relative vertical movement between the two.

Therefore we suggest that the dome-and-basin architecture of the Fuping Massif formed in response to a regionally coaxial deformation defined by crustal $\mathrm{N}-\mathrm{S}$ horizontal shortening and E-W horizontal stretching, together with a vertical (diapiric) rise of molten material, diatexites and anatectic granites contemporaneously with a large-scale thermal event around $2.1 \mathrm{Ga}$.

\subsection{The flat lying deformations, D2 and D3 events}

In a recent model, the Longquanguan Thrust has been interpreted as a hinterland thrust of a $\mathrm{N}-\mathrm{NW}$ directed orogen (Zhang et al., 2007). However, another view considers the Longquanguan Thrust as a regional scale flat lying tectonic contact that enables emplacement of nappes of the Orthogneiss and Volcanite Unit (OVU) that crop out in the Wutaishan Massif, towards the SE upon the Fuping Massif ([Faure et al., 2007] and [Trap et al., 2007]; this study). Such thrust faults with a general NE-SW trend and top to the SE kinematics are well developed west of the Longquanguan Thrust, in the Wutaishan Massif and more to the west in the Lüliangshan Massif ([Faure et al., 2007] and [Trap et al., 2007]). Moreover, $2.1 \mathrm{Ga}$ granites also crop out in the Wutaishan and Lüliangshan massif but lie parallel to the D2 fabric with NE-SW trending of the S2 foliation and exhibit a pervasive ductile deformation with a consistent top to the SE shearing. As described above, the major part of the Fuping Massif did not experience the D2 deformation responsible for crustal slicing and nappe stacking towards the SE. In this consideration, the Longquanguan Thrust represents the frontal thrust of the TNCB of which the inner zones are located more to the west in the Lüliangshan Massif. ${ }^{40} \mathrm{Ar}-{ }^{39} \mathrm{Ar}$ dating argues that the Pingshan normal fault occurred at $1830 \pm 12 \mathrm{Ma}$, and therefore represents the latest ductile deformation stage of the TNCB while the thickened crust was thinning.

The tectonic setting of this late Paleoproterozoic collisional orogen is still debated ([Kusky and Li, 2003], [Zhao et al., 2004], [Faure et al., 2007], [Trap et al., 2007] and [Zhang et al., 2007]). Nevertheless there is a general agreement to acknowledge that the TNCB shows many 
similarities with Phanerozoic collisional belts. In the Fuping massif, our structural study of the D2 and D3 events is in agreement with this view.

\subsection{Changes in crustal rheology during the Paleoproterozoic in the Fuping Massif}

The three current models that are proposed in order to explain the evolution and the amalgamation of the North China Craton (e.g., [Kusky and Li, 2003], [Zhao et al., 2004] and [Faure et al., 2007]) are all uniformitarian, i.e. they interpret the tectonic processes that took place in the North China Craton between $2.5 \mathrm{Ga}$ and $1.8 \mathrm{Ga}$ as similar to those of Phanerozoic times. Lithosphere plate mobility is advocated to account for arc magmatism, ophiolitic mélange, continental subduction, syn to late collisional crustal melting and foreland basin sedimentation. Zhao et al. (2004) suggest that oceanic subduction started at $2.5 \mathrm{Ga}$ and that subsequent collision occurred at $1.8 \mathrm{Ga}, 800 \mathrm{Ma}$ later. During this long time span, the rheology of the continental crust did not change but behaved as the present one. There is a growing consensus that plate tectonics has been an active component of Earth dynamics back to the Hadean (i.e., Cawood et al., 2006). However, the rheological behaviour of the continental crust was certainly different for older orogens due to a higher thermal regime and rather fast mantle convection ([Richter, 1984] and [Marshak, 1999]). Because during Archean and Paleoproterozoic the mantle was hotter than presently, some geologists suggest that the continental crust was also hotter than present (e.g., Percival, 1994). On the contrary, other researchers argue that the continental crust was not substantially hotter than today because it may lie above a thick lithospheric root acting as a thermal shield ([Bickle, 1986] and [Sandiford, 1989]).

In the Fuping massif, the dome-and-basin architecture formed in response to a regionally coaxial deformation defined by crustal N-S horizontal shortening and E-W horizontal stretching, contemporaneous with a large-scale thermal event. Such high thermal conditions together with the homogeneity in the character of the deformation suggest that the lithosphere should be rather hot and consequently the crust was mechanically softened. Deformation of a weak lithosphere associated with a high thermal regime is not restricted to the Archean but is also called upon in numerous Paleoproterozoic belts, such as the Scandinavian Svecofennides (e.g. Cagnard et al., 2006) or the 2.1 Ga granite-greenstone terrains of West Africa which formed in response to interference between diapiric and regional tectonics (Pons et al., 1995) similar to the Fuping area.

Marshak (1999) considered some implications of high temperature gradients in the crust in relation to deformation style, and especially for shear zone initiation and amplification. According to these authors, Paleoproterozoic mylonites would be restricted to a thin portion of the upper crust that would rarely be preserved, while high-grade shear zones yielding gneissic tectonites, might develop at depths where mylonites form presently. No flat lying mylonitic shear zones developed during the 2.1 Ga tectonic event but gneissic tectonites formed along migmatitic dome flanks. The Longquanguang Thrust and the Pingshan Fault are kilometre-scale mylonitic shear zones developed at a lower thermal regime around 1.9$1.8 \mathrm{Ga}$. The difference in the deformation style between the 2.1 and the $1.9-1.8$ orogeny could be viewed as a consequence of a regional cooling of the continental crust during the Paleoproterozoic. When dealing with the tectonic processes and deformation styles of the continental crust, the Neoarchean-Paleoproterozoic appears as a transitional period in the earth history. This statement could also stand for the North China Craton. 


\section{Conclusion}

The structural study of the Fuping massif provides an example of superimposed tectonic styles during the Paleoproterozoic evolution of the North China Craton. Structural elements developed at 1.9-1.8 Ga, characterized by flat-lying syn-metamorphic foliation and ductile shearing are quite similar to those encountered in Phanerozoic collisional belts. Although its geodynamic significance is not clearly settled yet, an earlier event, dated at ca. 2.1 Ga is characterized by E-W elongated granitic and migmatitic domes. Dome emplacement is the result of vertical (diapiric) rise of molten material, diatexites and anatectic granites, in a regional strain field characterized by $\mathrm{N}-\mathrm{S}$ shortening and $\mathrm{E}-\mathrm{W}$ stretching. Therefore, a new orogenic event dated at $2.1 \mathrm{Ga}$ has to be considered in the evolution of the Fuping Massif within the North China Craton from $2.7 \mathrm{Ga}$ to $1.8 \mathrm{Ga}$. Other evidence for a $2.1 \mathrm{Ga}$ event is found in several places in the North China Craton (e.g. [Yu and Li, 1997] and [Wilde et al., 2005]). Nevertheless, additional work at a greater scale is necessary before reaching a satisfactory interpretation of the place of the Fuping dome-and-basin domain in the $2.1 \mathrm{Ga}$ geodynamic evolution of the whole North China Craton. Finally, such a difference in tectonic styles is evidence for changes in the lithospheric rheological behaviour due to its cooling during Paleoproterozoic, in the North China Craton.

\section{Acknowledgements}

The field work for this research was financially supported by a National Science Foundation of China grant no. 40472116. ${ }^{40} \mathrm{Ar}-{ }^{39} \mathrm{Ar}$ and U-Pb LA-ICP-MS analyses were performed at the University of Montpellier II, France.

\section{References}

Bai, 1986 J. Bai, The Precambrian crustal evolution of the Wutaishan area. In: J. Bai, Editor, The Early Precambrian Geology of Wutaishan, Tianjin Science and Technology Press, Tianjin (1986), pp. 376-383 (in Chinese).

Bai and Dai, 1998 J. Bai and F.Y. Dai, Archean crust of China. In: X.Y. Ma and J. Bai, Editors, Precambrian Crust Evolution of China, Springer-Geological Publishing House, Beijing (1998), pp. 15-86.

Bickle, 1986 M.J. Bickle, Global thermal histories, Nature 319 (1986), pp. 13-14.

Bouchez et al., 1992 J.L. Bouchez, C. Delas, G. Gleizes, A. Nedelec and M. Cuney, Submagmatic microfractures in granites, Geology 20 (1992), pp. 35-38.

Bouhallier et al., 1993 H. Bouhallier, P. Choukroune and M. Ballevre, Diapirism, bulk homogeneous shortening and transcurrent shearing in the Archaean Dharwar craton: the Holenarsipur area, southern India, Precambrian Res. 63 (1993), pp. 43-58.

Bouhallier et al., 1995 H. Bouhallier, D. Chardon and P. Choukroune, Strain patterns in Archaean dome and basin structures: the Darwar craton (Karnakata, South India), Earth Planet. Sci. Lett. 135 (1995), pp. 57-75.

Bruguier et al., 2001 O. Bruguier, P. Télouk, A. Cocherie, A.M. Fouillac and F. Albarède, Evaluation of $\mathrm{Pb}-\mathrm{Pb}$ and $\mathrm{U}-\mathrm{Pb}$ laser ablation ICP-MS zircon dating using matrix-matched 
calibration samples with a frequency quadrupled (266 nm) Nd-YAG laser. Geostandards Newslett, J. Geostandards Geoanal. 25 (2001), pp. 361-373

Burg and Vanderhaeghe, 1993 J.P. Burg and O. Vanderhaeghe, Structures and way-up criteria in migmatites, with application to the Velay dome (French Massif Central), J. Struct. Geol. 15 (1993), pp. 1293-1301.

Cagnard et al., 2006 F. Cagnard, J.P. Brun and D. Gapais, Modes of thickening of analogue weak lithospheres, Tectonophysics 421 (2006), pp. 145-160.

Cawood et al., 2006 P.A. Cawood, A. Kröner and S. Pisarevsky, Precambrian plate tectonics: criteria and evidence, J. Geol. Soc. Am. 16 (2006), pp. 4-11.

Chardon et al., 1996 D. Chardon, P. Choukroune and M. Jayananda, Strain patterns, décollement and incipient sagducted greenstone terrains in South India, J. Struct. Geol. 18 (1996), pp. 991-1004.

Cheng et al., 2001 Y.Q. Cheng, Y.S. Wan, J.F. Gao and R. Ma, Petrographic Characteristics of three anatectically transformed metamorphic rock types of the Fuping Group - complex of the Xiaojue Region, Pingshan, Hebei. Geol. Rev. 47 (2001), pp. 1-8 (in Chinese with English abstract).

Choukroune et al., 1993 P. Choukroune, B. Auvray, B.M. Jahn, T. Chen, Y. Geng and D. Liu, Coupe structurale de la croute Archéenne en Hebei (Craton sino-coréen, Chine du nord), C.R. Acad. Sci. Paris 316 (1993), pp. 669-675.

Choukroune et al., 1995 P. Choukroune, H. Bouhallier and N.T. Arndt, Soft lithosphere during periods of Archaean crustal growth or crustal reworking. In: M.P. Coward and A. Ries, Editors, Early Precambrian Processes, Special Publication vol. 95, Geological Society, London (1995), pp. 67-86.

Collins et al., 1998 W.J. Collins, M.J. Van Kranendonk and C. Teyssier, Partial convective overturn of Archaean crust in the east Pilbara Craton, Western Australia: driving mechanisms and tectonic implications, J. Struct. Geol. 20 (1998), pp. 1405-1424.

Dalrymple, 1989 G.B. Dalrymple, The GLM continuous laser system for ${ }^{40} \mathrm{Ar} /{ }^{39} \mathrm{Ar}$ dating: Description and performance characteristics. In: W.C. Shanks and R. Criss, Editors, New Frontiers in Stable Isotope Research, US Geol. Soc. Bull. 1890 (1989), pp. 89-96.

Faure et al., 2007 M. Faure, P. Trap, W. Lin, P. Monié and O. Bruguier, The formation of the North China Craton by two Palaeoproterozoic continental collisions in Lüliang-HengshanWutaishan-Fuping massifs, Episodes 30 (2007), pp. 1-12.

Greenfield et al., 1996 J.E. Greenfield, G.L. Clarke, M. Bland and D.J. Clark, In-situ migmatite and hybrid diatexite at Mt Stafford, central Australia, J. Metamorphic Geol. 14 (1996), pp. 413-426.

Guan, 2000 Guan, H., 2000. The Fuping Complex and its significance in early Precambrian crustal evolution of Sino-Korean Craton. PhD thesis, The University of Hong Kong, Hong Kong, 223 pp. 
Guan et al., 2002 H. Guan, M. Sun, S.A. Wilde, X.H. Zhou and M.G. Zhai, SHRIMP U-Pb zircon geochronology of the Fuping Complex: implications for formation and assembly of the North China craton, Precambrian Res. 113 (2002), pp. 1-18.

Hames and Bowring, 1994 W.E. Hames and S.A. Bowring, An empirical evaluation of the argon diffusion geometry in muscovite, Earth Planet. Sci. Lett. 124 (1994), pp. 161-167.

Hao et al., 1995 J. Hao, K.Y. Wang and S.P. Zhou, Discussion on stratigraphic and tectonic features of "Longquanguan Group" in the south west piedmont of Wutai mountain and relevant problems, Sci. Geol. Sin. 30 (1995), pp. 183-189 (in Chinese with English abstract). HBGMR (Henan Bureau of Geology and Mineral Resources), 1989 HBGMR (Henan Bureau of Geology and Mineral Resources), Regional Geology of Shanxi Province, Geological Publishing House, Beijing (1989) 742 pp.

Hibbard, 1987 M.J. Hibbard, Deformation of incompletely crystallized magma systems: granitic gneisses and their tectonic implications, J. Geol. 95 (1987), pp. 543-561.

Holdaway and Murkhopadhyay, 1993 M.J. Holdaway and B.A. Murkhopadhyay, A reevaluation of the stability relations of andalusite: thermochemical data and phase diagram for the aluminum silicates, Am. Mineral. 78 (1993), pp. 298-315.

Kröner et al., 2005 A. Kröner, S.A. Wilde, J.H. Li and K.Y. Wang, Age and evolution of a late Archean to early Palaeoproterozoic upper to lower crustal section in the Wutaishan/Hengshan/ Fuping terrain of northern China, J. Asian Earth Sci. 24 (2005), pp. 577-596.

Kusky and Li, 2003 T.M. Kusky and J.H. Li, Paleoproterozoic tectonic evolution of the North China craton, J. Asian Earth Sci. 22 (2003), pp. 23-40.

Li and Qian, 1991 J.H. Li and X.L. Qian, A study of Longquanguan shear zone in the northern part of the Taihang Mountain, Shanxi Geol. 6 (1991), pp. 17-29 (in Chinese).

Li et al., 2004 J.H. Li, S.L. Niu and Z. Chen, Discovery of the deep thrusting structure in the Taihangshan area and its tectonic implications, Adv. Natural Sci. 14 (2004), pp. 1118-1127.

Liu et al., 1985 D. Liu, Y. Page, R.W. Compston and W.J. Wu, U-Pb zircon geochronology of late Archean metamorphic rocks in the Taihangshan-Wutaishan area North China, Precambrian Res. 27 (1985), pp. 85-109

Liu, 1996 S.W. Liu, Study on the P-T path of granulites in Fuping area, Hebei Province, Geol. J. Univ. 2 (1996), pp. 75-84 (in Chinese with English abstract).

Liu and Liang, 1997 S.W. Liu and H.H. Liang, Metamorphism of Al-rich gneisses from the Fuping Complex, Taihang Mountain, China, Acta Petrol. Sin. 13 (1997), pp. 303-312. Liu et al., 2000 S.W. Liu, H.H. Liang, G.C. Zhao, Y.G. Hua and A.H. Jian, Isotopic chronology and geological events of Precambrian complex in Taihangshan region, Sci. China 43 (2000), pp. 386-393. 
Liu et al., 2002a S.W. Liu, Y. Pan, J.H. Li, G.G. Li and J. Zhang, Geological and isotopic geochemical constraints on the evolution of the Fuping Complex, North China Craton, Precambrian Res. 117 (2002), pp. 41-56.

Liu et al., 2002b S.W. Liu, J.H. Li, Y.M. Pan, J. Zhang and Q.G. Li, An Archean continental block in the Taihangshan and Hengshan regions: constraints from geochronology and geochemistry, Prog. Nat. Sci. 12 (2002), pp. 568-576.

Liu et al., 2004 S.W. Liu, Y.M. Pan, Q.L. Xie, J. Zhang and Q.G. Li, Archean geodynamics in the Central Zone, North China Craton: constraints from geochemistry of two contrasting series of granitoids in the Fuping and Wutai complexes, Precambrian Res. 130 (2004), pp. 229-249.

Liu et al., 2006 S.W. Liu, G.C. Zhao, S.A. Wilde, G. Shu, M. Sun, Q. Li, W. Tian and J. Zhang, Th-U-Pb monazite geochronology of the Luliang and Wutai complexes: constraints on the tectonothermal evolution of the Trans-North China orogen, Precambrian Res. 148 (2006), pp. 205-224

Ludwig, 2000 K.R. Ludwig, Users Manual for ISOPLOT/EX, A Geochronological Toolkit for Microsoft Excel (Version 2), Special Publication vol. 1a, Berkeley Geochronology Center (2000) 43 pp..

Marshak, 1999 S. Marshak, Deformation style way back when: thoughts on the contrasts between Archean: paleoproterozoic and contemporary orogens, J. Struct. Geol. 21 (1999), pp. $1175-1182$.

Marmo, 1971 V. Marmo, Granite Petrology and the Granite Problem, Elsevier, Amsterdam (1971) pp. 1-244.

McLaren et al., 2005 S. McLaren, M. Sandiford and R. Powell, Contrasting styles of Proterozoic crustal evolution: a hot-plate tectonic model for Australian terranes, Geol. Soc. Am. 33 (2005), pp. 673-676

Menhert, 1968 K.R. Menhert, Migmatites and the Origin of Granitic Rocks, Elsevier, Amsterdam (1968) 393 pp..

Monié et al., 1994 P. Monié, R.L. Torres-Roldan and A. Garcia-Casco, Cooling and exhumation of the western Betic Cordilleras, ${ }^{40} \mathrm{Ar} /{ }^{40} \mathrm{Ar}$ thermochronological constraints on a collapsed terrane, Tectonophysics 238 (1994), pp. 353-379.

Monié et al., 1997 P. Monié, R. Caby and M.H. Arthaud, The neoproterozoic Brasiliano orogeny in northeast Brazil: ${ }^{40} \mathrm{Ar} /{ }^{39} \mathrm{Ar}$ and petrostructural data from Ceará, Precambrian Res. 81 (1997), pp. 241-264.

Pawley and Collins, 2002 M.J. Pawley and W.J. Collins, The development of contrasting structures during the cooling and crystallisation of a syn-kinematic pluton, J. Struct. Geol. 24 (2002), pp. 469-483.

Percival, 1994 J.A. Percival, Archean high-grade metamorphism. In: K.C. Condie, Editor, Archean Crustal Evolution, Elsevier, Amsterdam (1994), pp. 357-410 
Percival et al., 2001 J.A. Percival, R.A. Stern and T. Skulski, Crustal growth through successive arc magmatism, northeastern Superior Province, Canada, Precambrian Res. 109 (2001), pp. 203-238

Pons et al., 1995 J. Pons, P. Barbey, D. Dupuis and J.M. Léger, Mechanisms of pluton emplacement and structural evolution of the 2.1 Ga juvenile continental crust: the Birimien of southwestern Niger, Precambrian Res. 70 (1995), pp. 281-305.

Richter, 1984 F.M. Richter, Regionalized models for thermal evolution of the earth, Earth Planet. Sci. Lett. 68 (1984), pp. 471-484.

Sandiford, 1989 M. Sandiford, Secular trends in the thermal evolution of metamorphic terrains, Earth Planet. Sci. Lett. 95 (1989), pp. 85-96.

Sawyer, 1999 E.W. Sawyer, Criteria for the recognition of partial melting, Phys. Chem. Earth 24 (1999), pp. 269-279. SBGMR (Shanxi Bureau of Geology and Mineral Resources), 1989 SBGMR (Shanxi Bureau of Geology and Mineral Resources), Regional Geology of Shanxi Province, Geological Publishing House, Beijing (1989) 780 pp..

Scheck et al., 2003 M. Scheck, U. Bayer and B. Lewerenz, Salt movements in the Northeast German Basin and its relation to major post-Permian tectonic phases - results from 3D structural modelling, backstripping and reflection seismic data, Tectonophysics 361 (2003), pp. 277-299.

Sun and Guan, 2001 M. Sun and H. Guan, Zircon U-Pb ages of the Fuping Complex and their implications: some comments on the geochronological study of the precambrian high-grade metamorphic terranes, Acta Petrol. Sin. 17 (2001), pp. 145-156 (in Chinese with English abstract).

Sun et al., 2004 Z.L. Sun, J.R. Li, C.R. Liu, Y.S. Zhang, Y.H. Yang and W.S. Yan, Another view on the Longquanguan Ductile Shear Zone, Geol. Survey Res. 27 (2004), pp. 92-100 (in Chinese with English abstract).

Tang and Liu, 1997 X.M. Tang and S.W. Liu, Extensional deformation belt in the Archean metamorphic rocks in the Northern Taihang mountains, J. Peking Univ. 33 (1997), pp. $447-$ 455.

Teyssier and Whitney, 2002 C. Teyssier and D.L. Whitney, Gneiss domes and orogeny, Geology 30 (2002), pp. 1139-1142

Trap et al., 2007 P. Trap, M. Faure, W. Lin and P. Monié, Late Palaeoproterozoic (1900$1800 \mathrm{Ma}$ ) nappe stacking and polyphase deformation in the Hengshan-Wutaishan area: implication for the understanding of the Trans-North China Belt, North China Craton, Precambrian Res. 156 (2007), pp. 85-106

Vanderhaeghe, $2001 \mathrm{O}$. Vanderhaeghe, Melt segregation, pervasive melt migration and magma mobility in the continental crust: the structural record from pores to orogens, Phys. Chem. Earth 26 (2001), pp. 213-223. 
Vernon, 1991 R.H. Vernon, Questions about myrmekite in deformed rocks, J. Struct. Geol. 13 (1991), pp. 979-985.

Vernon, 2000 R.H. Vernon, Review of microstructural evidence of magmatic and solid-state flow, Electron. Geosci. 5 (2) (2000), pp. 1-23.

Wan et al., 2002 Y.S. Wan, Y.Q. Cheng, J.F. Gao and C.H. Yang, Study on geochemistry of hornblendic rocks and their anatectic derivatives of the Fuping Group in the Xiaojue Area, Hebei Province, Acta Geol. Sin. 23 (2002), pp. 429-434.

Wang et al., 1991 K.Y. Wang, J.L. Li and L.Q. Liu, Petrogenesis of the Fuping grey gneisses, Sci. Geol. Sin. 26 (1991), pp. 254-267 (in Chinese).

Whitney et al., 2004 D.L. Whitney, C. Teyssier and O. Vanderhaeghe, Gneiss domes and crustal flow, Special Paper vol. 380, Geological Society of America (2004) 15-33.

Wiedenbeck et al., 1995 M. Wiedenbeck, P. Allé, F. Corfu, W.L. Griffin, M. Meier, F. Oberli, A. von Quadt, J.C. Ruddick and W. Spiegel, Three natural zircon standards for U-Th-Pb, LuHf, trace element and REE analyses, Geostandards Newslett. 19 (1995), pp. 1-23.

Wilde et al., 1998 S.A. Wilde, P.A. Cawood, K.Y. Wang and A. Nemchin, SHRIMP U-Pb zircon dating of granites and gneisses in the Taihangshan-Wutaishan area: implications for the timing of crustal growth in the North China Craton, Chin. Sci. Bull. 43 (1998), pp. 144-145.

Wilde et al., 2004 S.A. Wilde, P.A. Cawood, K.Y. Wang, A. Nemchin and G.C. Zhao, Determining Precambrian crustal evolution in China: a case study from Wutaishan, Shanxi Province, demonstrating the application of precise SHRIMP U-Pb geochronology. In: J. Malpas, C.J.N. Fletcher, J.R. Ali and J.C. Aitchison, Editors, Aspects of the Tectonic Evolution of China, Special Publication vol. 226, Geological Society, London (2004), pp. 525.

Wilde et al., 2005 S.A. Wilde, P.A. Cawood, K.Y. Wang and A. Nemchin, Granitoid evolution in the late Archean Wutai Complex, North China Craton, J. Asian Earth Sci. 24 (2005), pp. 597-613.

Wu et al., 1989 J.S. Wu, Y.S. Geng, H.F. Xu, L.G. Jin, S.Y. He and S.W. Sun, Metamorphic geology of Fuping Group, J. Chin. Inst. Geol. 19 (1989), pp. 1-213 (in Chinese).

Wu et al., 1991 J.S. Wu, Y.S. Geng, Q.H. Shen, D.Y. Liu, Z.L. Li and D.M. Zhao, The early Precambrian significant geological events in the North China Craton, Geological Publishing House, Beijing (1991) pp. 1-115 (in Chinese with English abstract).

Wu and Zhong, 1998 C.H. Wu and C.T. Zhong, The paleaoproterozoic SW-NE collision model for the central North China Craton, Prog. Precambrian Res. 21 (1998), pp. 28-50 (in Chinese).

Yang et al., 1986 Z. Yang, Y. Cheng and H. Wang, The Geology of China, Clarendon Press, Oxford (1986) 303 pp.. 
Yu and Li, 1997 J.H. Yu and H.M. Li, Ages of the Lüliang Group and its main metamorphism in the Lüliang Mountains, Shanxi: evidence from single-grain zircon U-Pb ages, Geol. Rev. 43 (1997), pp. 403-408.

Zhang et al., 1991 Z.Q. Zhang, J.S. Wu and X.J. Xe, REE, Rb-Sr and Sm-Nd ages of the Archean metamorphic rocks of the Lower Fuping Subgroup and their implications, Geochimica 2 (1991), pp. 118-126 (in Chinese).

Zhang et al., 2006a J. Zhang, G.C. Zhao, S. Li, M. Sun, S. Liu and C.Q. Yin, New U-Th-Pb geochronological constraints on the structural evolution of the Fuping Complex: implications for the tectonic processes of the Trans-North China orogen, IAGR Annual Convention \& International Symposium 2006 (2006), pp. 59-60 Hong Kong, China(abstract).

Zhang et al., 2006b J. Zhang, G.C. Zhao, S. Li, M. Sun and S. Liu, Structural geology of the Fuping complex: constraints on the tectonic evolution of the Trans-North China Orogen, AGU Western Pacific Geophysics Meeting (2006) Abstract No. TI2B-03.

Zhang et al., 2007 J. Zhang, G.C. Zhao, S.Z. Li, M. Sun, S.W. Liu, S.A. Wilde, A. Kröner and C.Q. Yin, Deformation history of the Hengshan Complex: implications for the tectonic evolution of the Trans-North China Orogen, J. Struct. Geol. 29 (2007), pp. 933-949.

Zhao et al., 1999 G.C. Zhao, P.A. Cawood and L.Z. Lu, Petrology and P-T history of the Wutai amphibolites: implications for tectonic evolution of the Wutai Complex, China, Precambrian Res. 93 (1999), pp. 181-199.

Zhao et al., 2000a G.C. Zhao, P.A. Cawood, S.A. Wilde and L.Z. Lu, Metamorphism of basement rocks in the Central Zone of the North China Craton: implications for Paleoproterozoic tectonic evolution, Precambrian Res. 103 (2000), pp. 55-88.

Zhao et al., 2000b G.C. Zhao, S.A. Wilde, P.A. Cawood and L.Z. Lu, Petrology and P-T path of the Fuping mafic granulites: implications for tectonic evolution of the central zone of the North China Craton, J. Metamorph. Geol. 18 (2000), pp. 375-391.

Zhao et al., 2002 G.C. Zhao, S.A. Wilde, P.A. Cawood and M. Sun, SHRIMP U-Pb zircon ages of the Fuping Complex: implications for late Archean to Paleoproterozoic accretion and assembly of the North China Craton, Am. J. Sci. 302 (2002), pp. 191-226

Zhao et al., 2004 G.C. Zhao, M. Sun, S.A. Wilde and J.H. Guo, Late Archean to Palaeoproterozoic evolution of the trans-North China Orogen: insights from synthesis of existing data from the Hengshan-Wutai-Fuping belt. In: J. Malpas, C.J.N. Fletcher, J.R. Ali and J.C. Aitchison, Editors, Aspects of the Tectonic Evolution of China, Special Publication vol. 226, Geological Society, London (2004), pp. 27-55.

Zhao et al., 2006 L. Zhao, J.J. Zhang and S.W. Liu, Syn-deformational granites of the Longquanguan ductile shear zone and their monazite electronic microprobe dating, Acta. Petrol. Mineral. 25 (2006), pp. 210-218. 


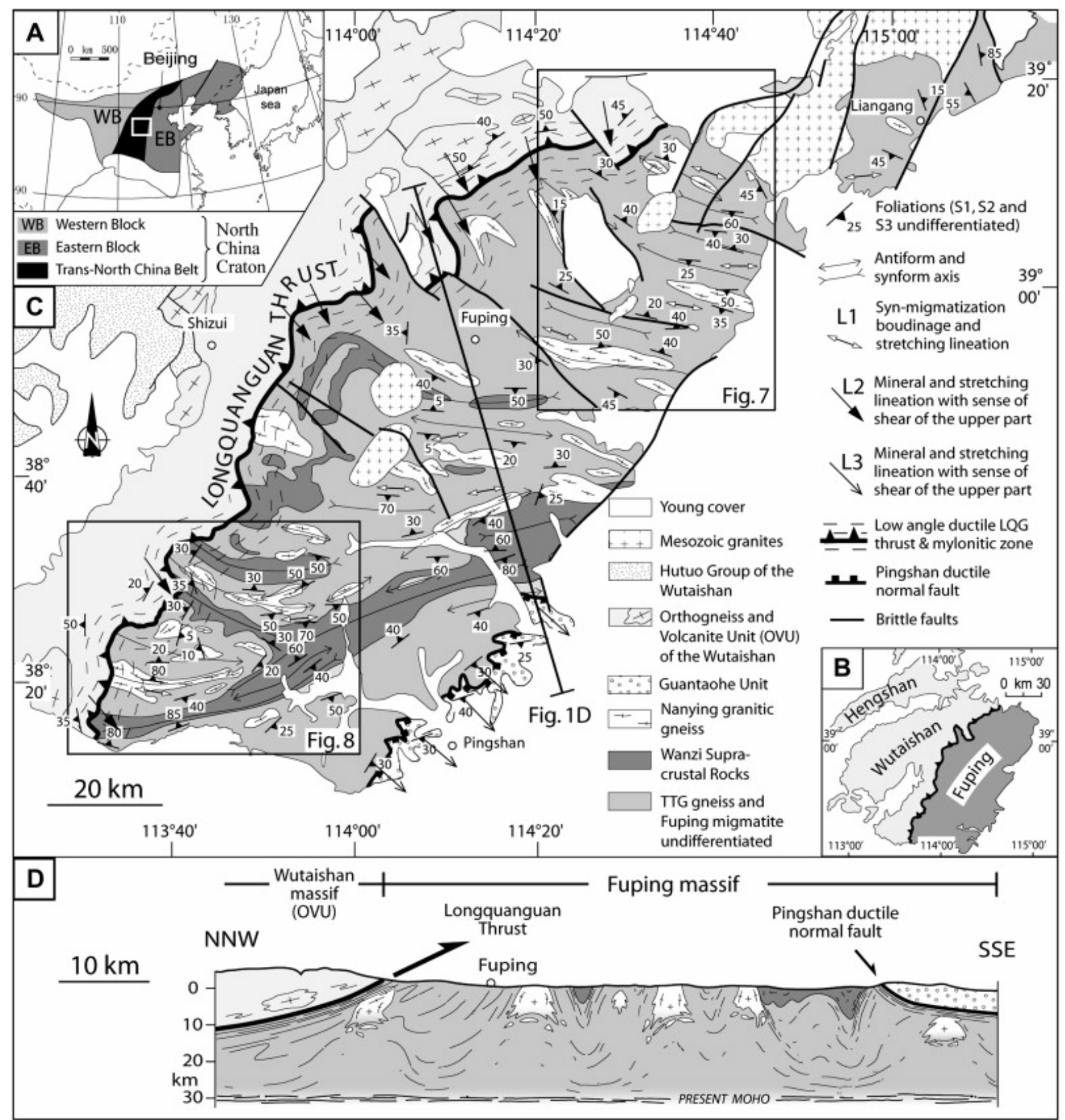

Fig. 1. (A) Location of the Trans-North-China Belt (TNCB) between the Western and Eastern Blocks within the North China Craton. (B) Geographic relationship of the Fuping Massif with the Hengshan-Wutaishan domain. (C) Geological map of the Fuping massif. (D) Simplified crustal-scale cross-section through the Fuping Massif, from the Longquanguan Thrust to the Gantaohe Unit. 

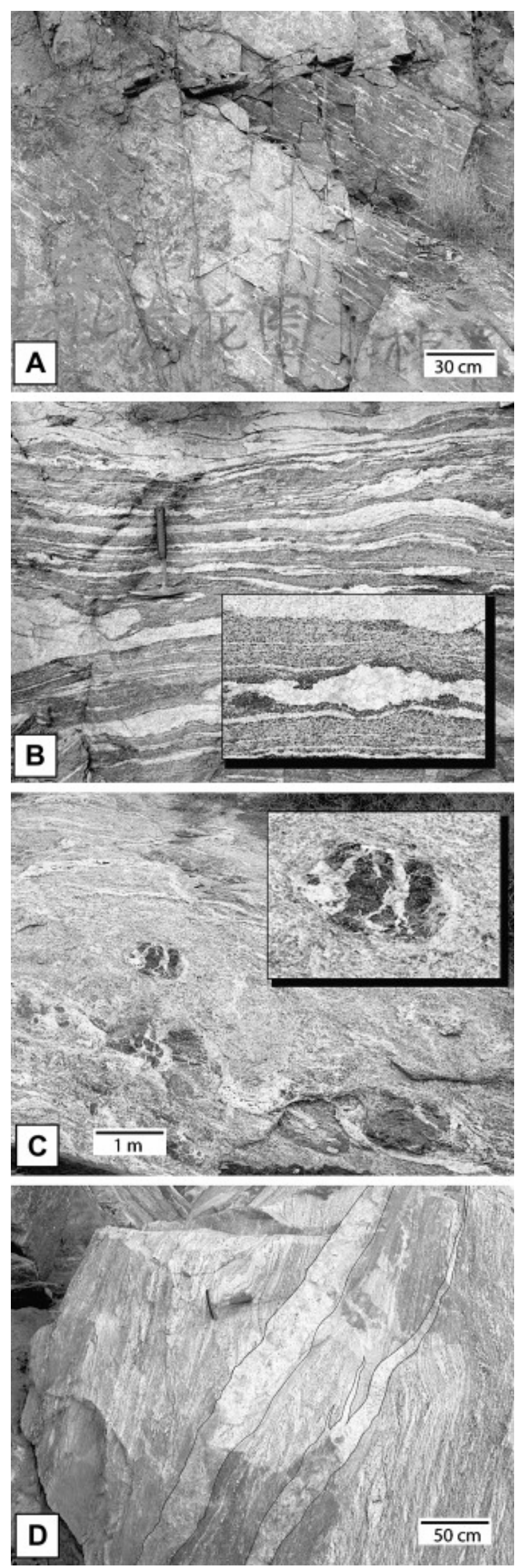
Fig. 2. Photographs of Fuping metatexites and diatexites. (A) Metatexite with a small proportion of leucosome formed in the beginning of the melting reaction

$\left(\mathrm{N} 38^{\circ} 48.845^{\prime} / \mathrm{E} 114^{\circ} 06.107^{\prime}\right)$. (B) Stromatic structure in metatexite with alternations of leucosome/paleosome. Insert: Pegmatoid leucosome surrounded by melanosomes (darkest area), both constitute the neosome formed in response to segregation from the paleosome $\left(\mathrm{N} 38^{\circ} 43.737^{\prime} / \mathrm{E}^{\circ} 114^{\circ} 16.535^{\prime}\right)$. (C) Diatexite with a schöllen structure defined by a prevalent trondhjemitic leucosome holding partially disrupted mafic enclaves. Insert: Synmigmatization boudinage of a mafic restite with melt occurring in the dilatant sites $\left(\mathrm{N} 38^{\circ} 57.283^{\prime} / \mathrm{E}^{\circ} 114^{\circ} 34.221^{\prime}\right)$. (D) Late vein-like leucosomes cross cutting the migmatitic foliation $\left(\mathrm{N} 38^{\circ} 19.565^{\prime} / \mathrm{E}^{\circ} 113^{\circ} 37.015^{\prime}\right)$. The veins are filled by the melt that come from the syn-folial leucosomes, illustrating the process of segregation, transposition and migration of the melt.
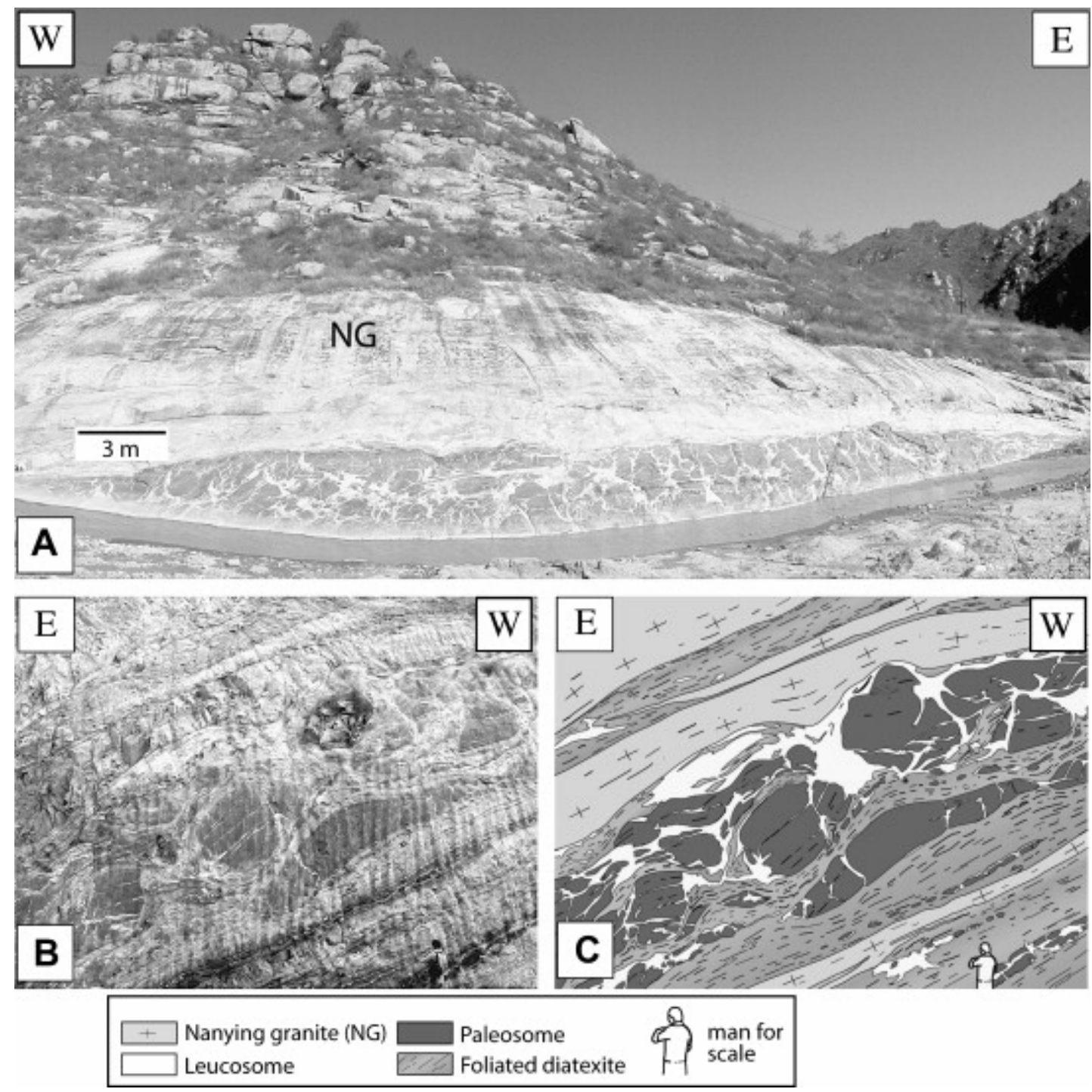

Fig. 3. (A) A 10-metre scale enclave of migmatite within the Nanying gneissic granite (NG). The migmatite enclave shows an agmatic structure characterized by angulose fragments of amphibolite surrounded by leucosome (N38 $\left.20.376^{\prime} / \mathrm{E} 113^{\circ} 36.953^{\prime}\right)$. (B and C) Picture (B) and hand drawing $(\mathrm{C})$ of a funnel-shaped intrusion of granitoid sheeted dykes parallel to the migmatitic foliation, within diatexite in the vicinity of a Nanying pluton (N38 $\left.41.351^{\prime} / \mathrm{E} 114^{\circ} 17.953^{\prime}\right)$. 


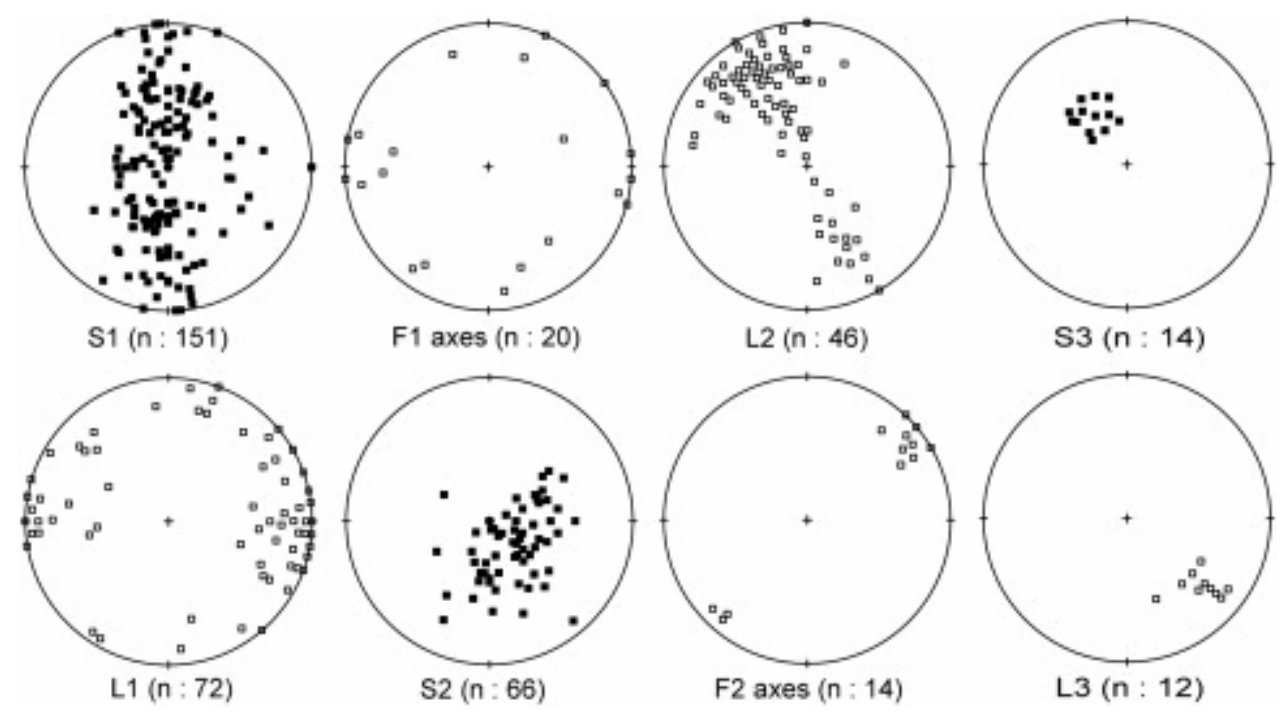

Fig. 4. Equal area, lower hemisphere Schmidt stereograms of S1, L1, F1, S2, L2, F2, S3 and L3. 



Fig. 5. Deformation features along the Longquanguan Thrust (A, B and C) and the Pingshan Fault (D, E and F). (A) Mylonitized gneiss, composed of well-developed layers of quartz ribbons within a matrix of biotite, feldspars and quartz. The foliation is flat lying and the lineation trends $\mathrm{N} 160^{\circ},\left(\mathrm{N} 38^{\circ} 54.879^{\prime} / \mathrm{E} 113^{\circ} 47.600^{\prime}\right)$. (B) Quartz-feldspar layer in a metavolcanite showing a top to the SE kinematics (N39 $\left.04.648^{\prime} / \mathrm{E} 113^{\circ} 07.487^{\prime}\right)$. (C) Top to the SE shear criteria marked by a sigma-type porphyroclast in an augen gneiss $\left(\mathrm{N} 39^{\circ} 04.820^{\prime} / \mathrm{E} 113^{\circ} 39.167^{\prime}\right)$. (D) Mylonitic zone within the Gantaohe sediments along the Pingshan Fault $\left(\mathrm{N} 38^{\circ} 12.749^{\prime} / \mathrm{E}^{\circ} 114^{\circ} 04.049^{\prime}\right)$. (E) Asymmetric pressure shadows around a feldspar porphyroclast indicating a top to the SE shearing; within the same mylonitic zone (same outcrop). (F) Top to the SE shear criteria shown by sigmoidal pattern of mica and feldspar aggregate, around the sigmoidal shape are ribbon quartz (sample FP154 dated at $1830 \pm 20 \mathrm{Ma}$ see Section 5.1.3) (N38 $\left.20.535^{\prime} / \mathrm{E} 114^{\circ} 12.775^{\prime}\right)$. 


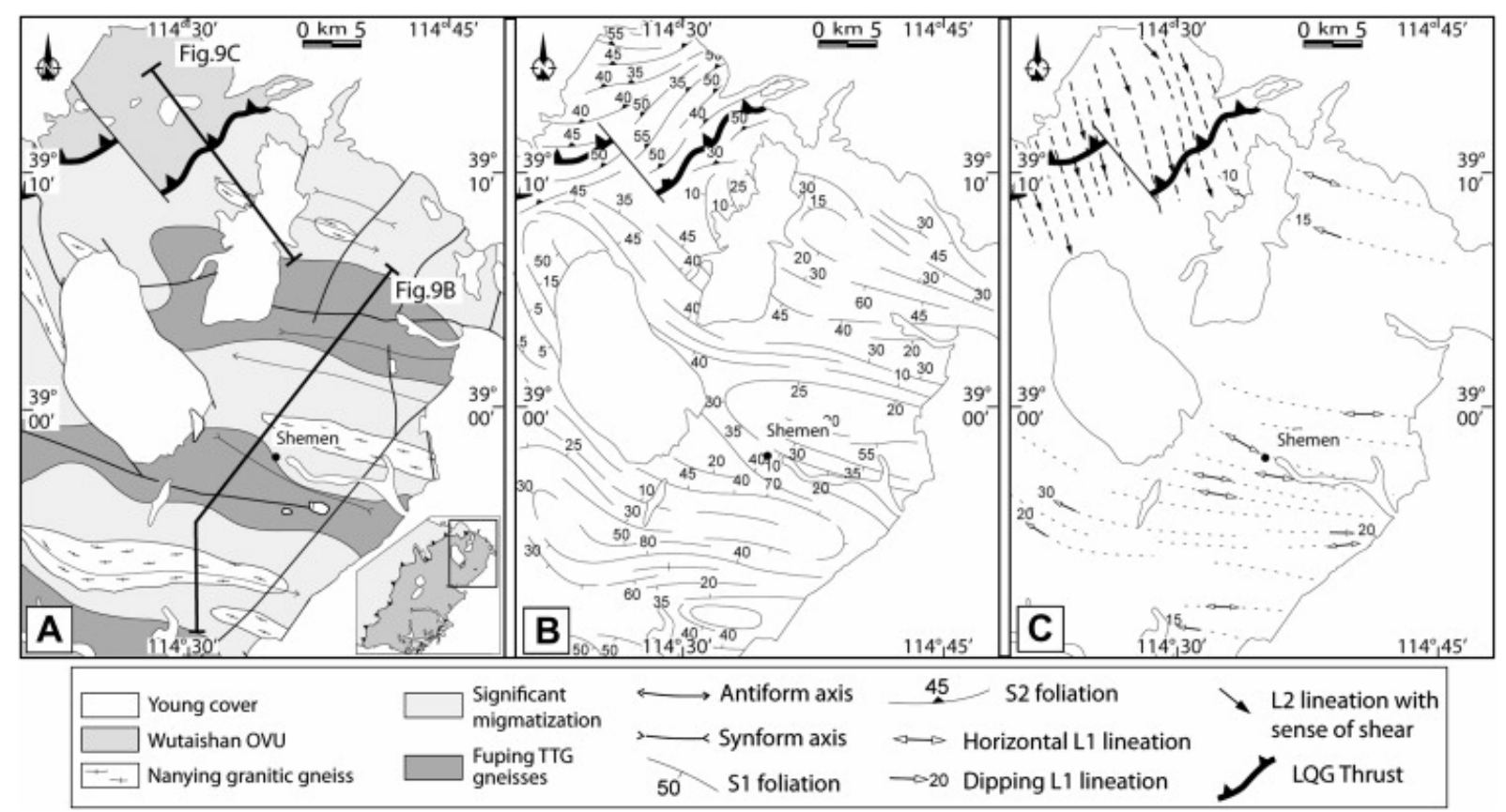

Fig. 6. Structural sketch maps of the northeastern part of the Fuping massif. (A) Geological map. (B) S1 and S2 foliation trajectories. (C) L1 and L2 lineation trajectories. 

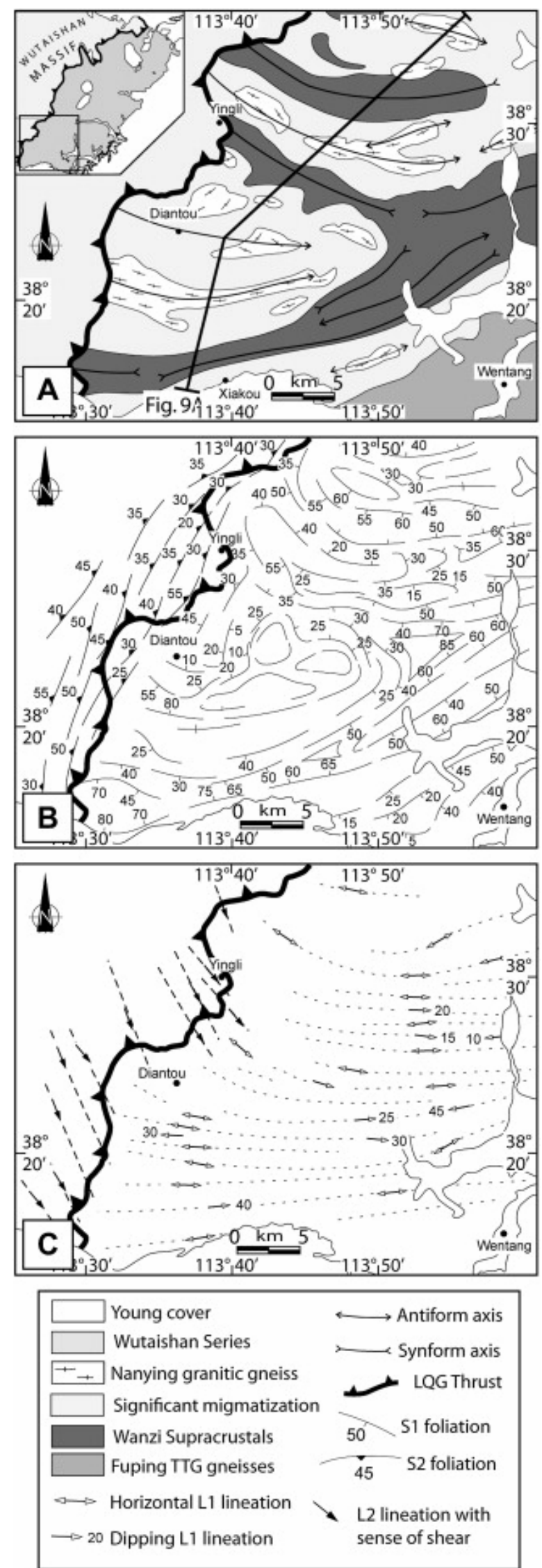

Fig. 7. Structural sketch maps of the southwestern part of the Fuping massif. (A) Geological map. (B) S1 and S2 foliation trajectories. (C) L1 and L2 lineation trajectories. 
A

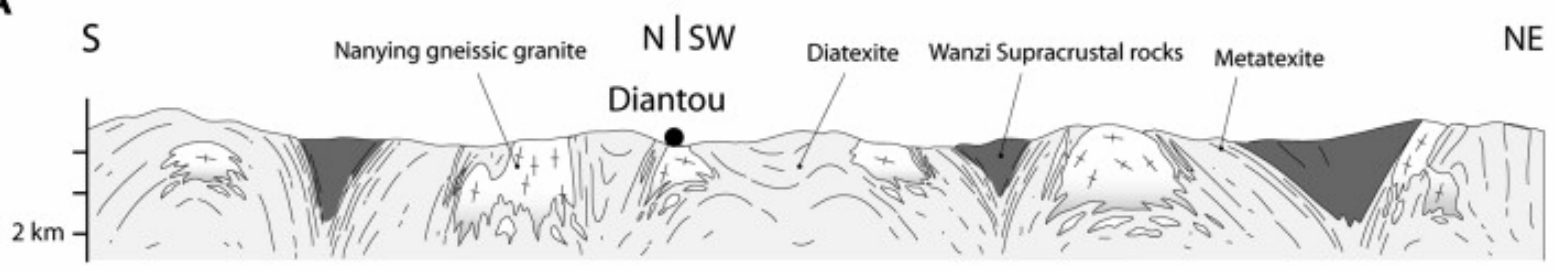

B

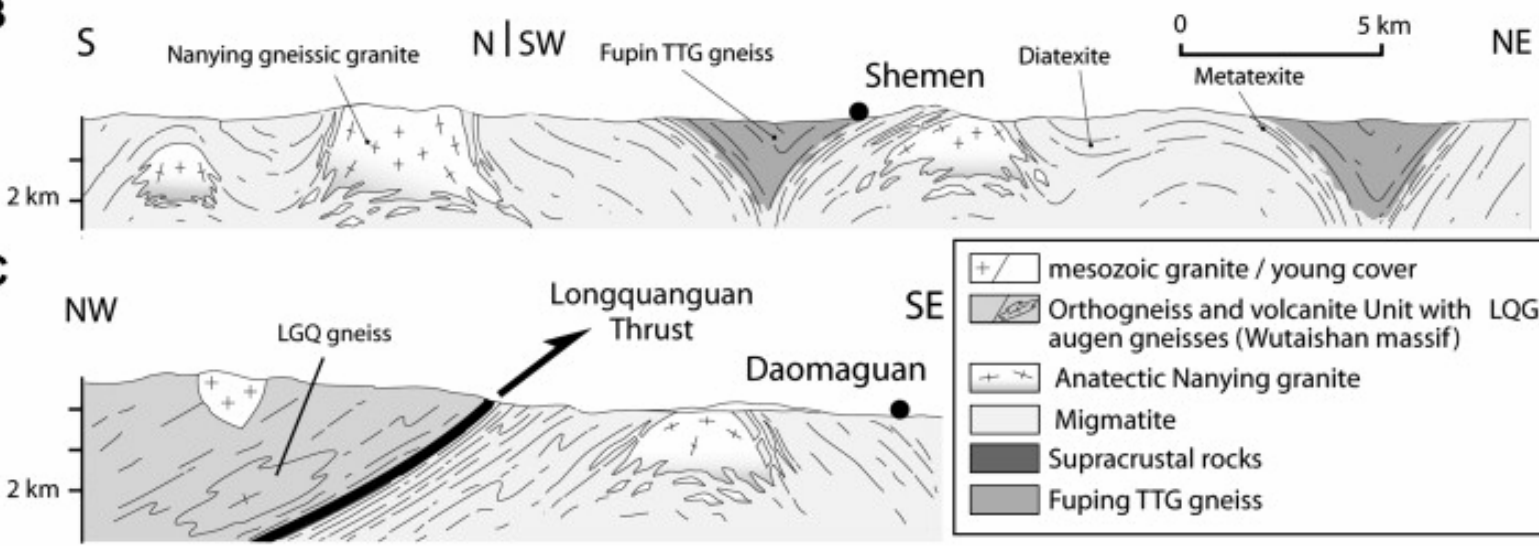

Fig. 8. (A) Cross-section through the south-western part of the Fuping massif (see Fig. 7 for location). (B and C) Cross-sections thought the north-eastern part of the Fuping massif (see Fig. 6 for location). 



Fig. 9. Photographs illustrating the syn-migmatitic D1 deformation. (A) Stromatic migmatite near top of a dome. Flattened lens-shaped with S-L fabrics and stretched mafic restites are evidence for horizontal flattening and E-W stretching. Upward channelized flow of the melt (arrowed) is well developed (N38 $\left.28.234^{\prime} / \mathrm{E} 113^{\circ} 53,004^{\prime}\right)$. (B) Syn-migmatitic layering with stretched restitic layers. Insert: asymmetric leucocratic pressure shadows around biotite-rich restite showing a top to the NE shearing, near the dome top. S1 is flat lying (N38 $\left.58.317^{\prime} / \mathrm{E} 114^{\circ} 21.237^{\prime}\right)$. (C) Sigmoidal leucosome showing a top to the SE shearing, in a foliated diatexite, S1 strikes N120E and dips $40^{\circ}$ to the NE and L1 trends N110E (N38 $\left.57.283^{\prime} / \mathrm{E} 114^{\circ} 34.221^{\prime}\right)$. (D) Drag fold developed at dome termination showing downward shearing. Note a saddle reef (arrowed) (N38 $\left.30.412^{\prime} / \mathrm{E} 113^{\circ} 52.594^{\prime}\right)$. 


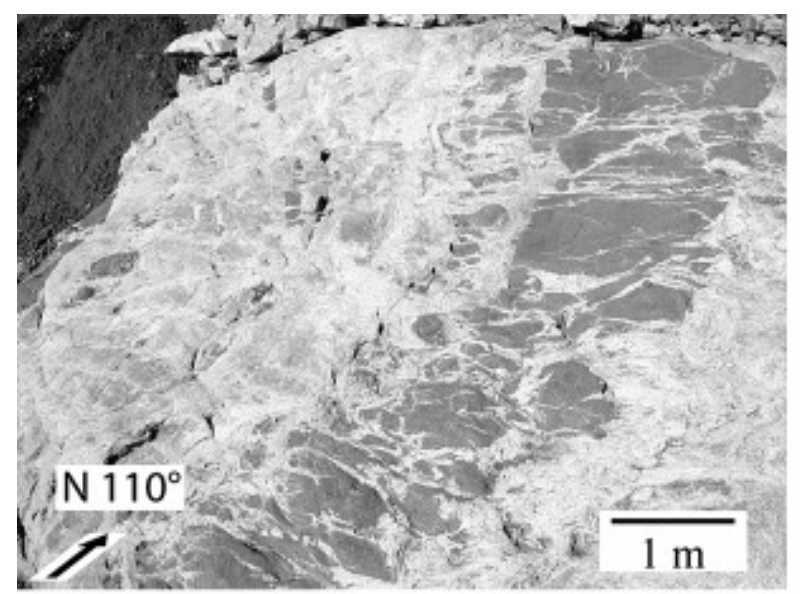

\section{a}
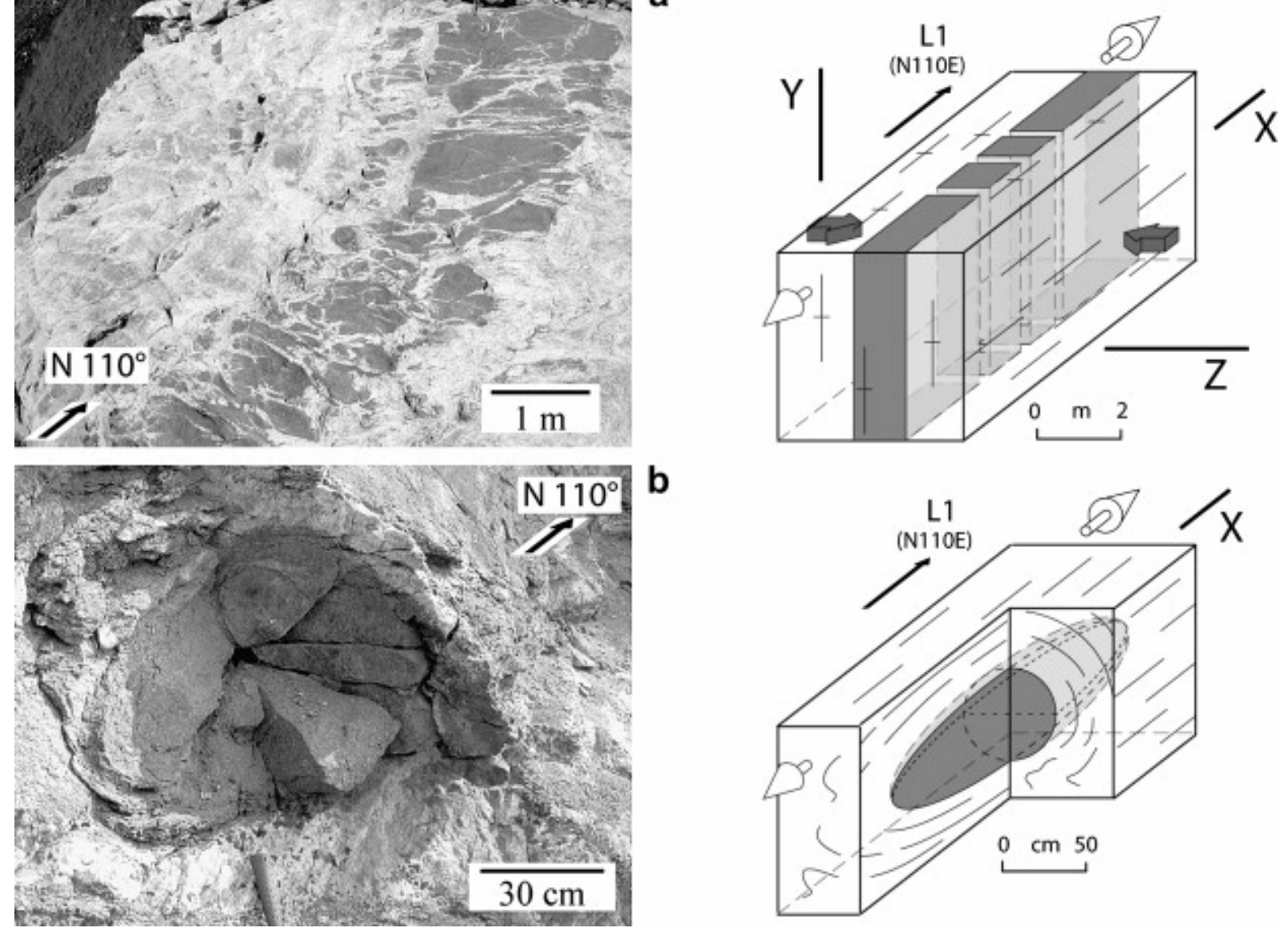

Fig. 10. Field evidence and schematic diagram of the two dominant deformations observed in the migmatite of the Dome-and-Basin Domain. (a) N110E vertical boudinage of a mafic layer, the intermediate finite strain axis $(Y)$ is vertical $\left(\mathrm{N} 38^{\circ} 19.565^{\prime} / \mathrm{E}^{\circ} 113^{\circ} 37.015^{\prime}\right)$. (b) Linear fabric indicated by an elongated amphibolite restite within the gneissic migmatite, the rounded shape of the restite in section perpendicular to $X$ axis ( $Y Z$ section) shows a prolate 3D shape that argues for a constrictional finite strain $\left(\mathrm{N} 38^{\circ} 56.177^{\prime} / \mathrm{E}^{\circ} 114^{\circ} 19.193^{\prime}\right)$. 


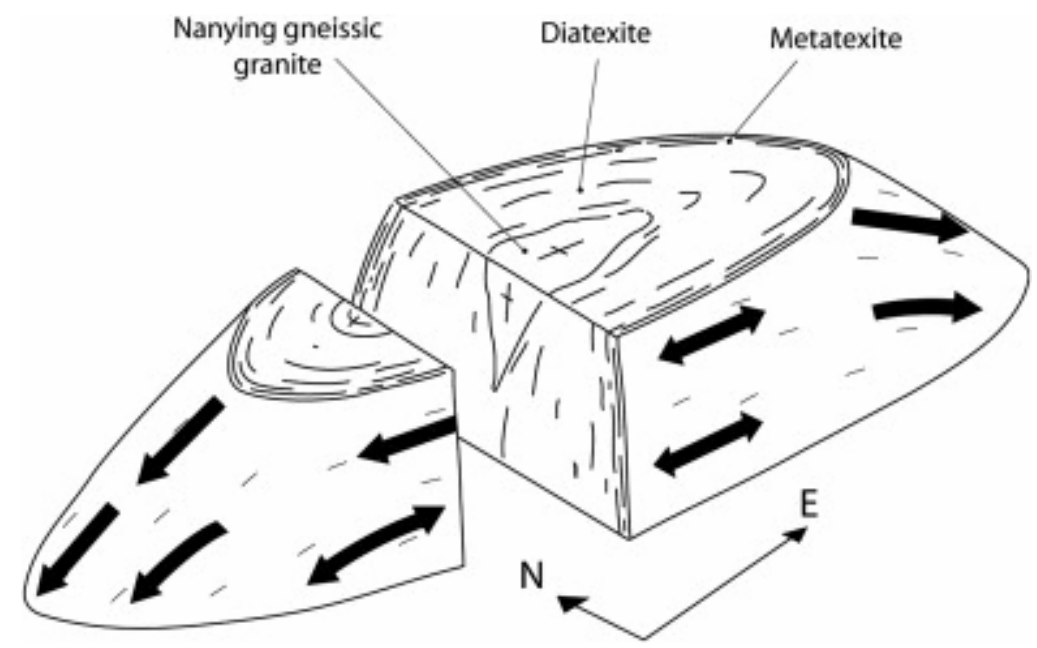

Fig. 11. Interpretative sketch of a single migmatitic dome of the Dome-and-Basin Domain showing top-moving downward kinematics at dome terminations and coaxial flow along dome flanks. 

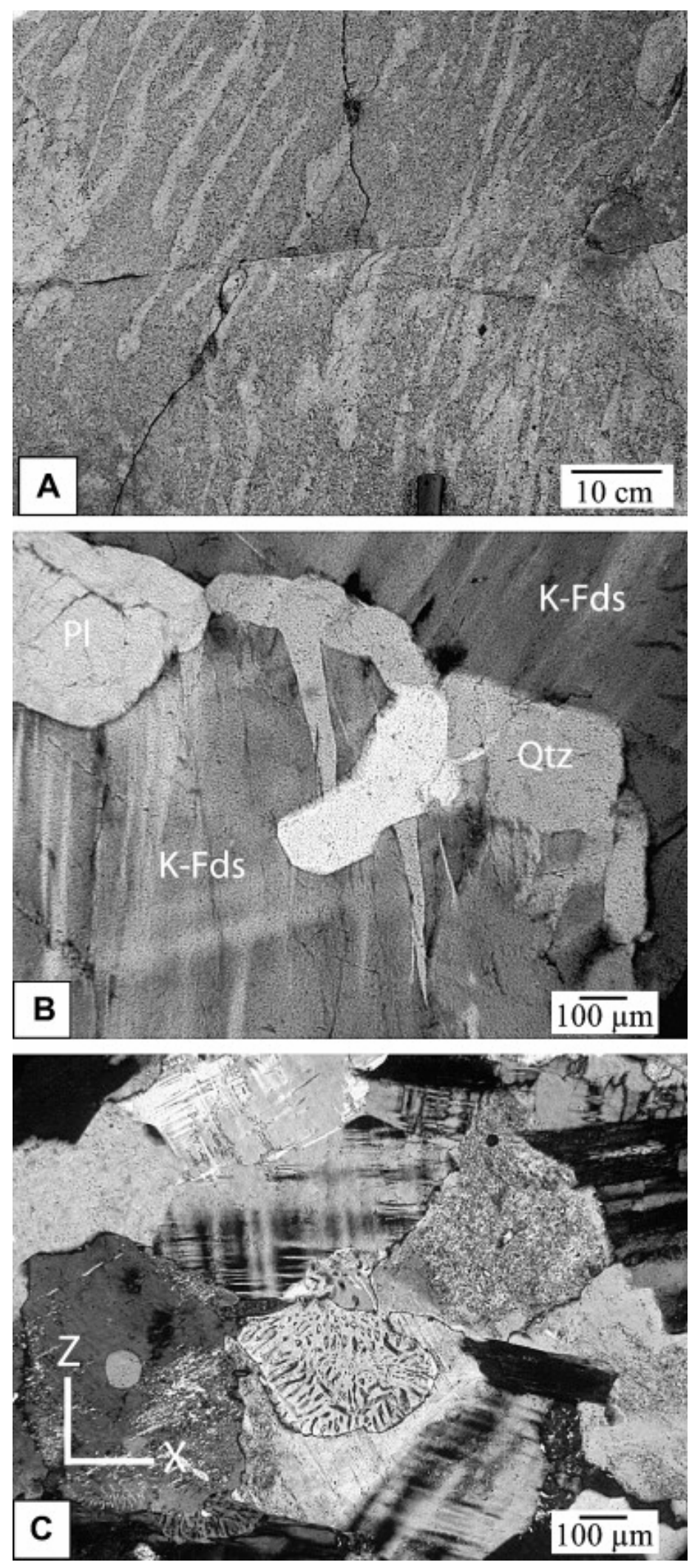

Fig. 12. (A) Magmatic foliation defined by pockets of quartz-feldspar composition formed by segregation during the late stage of crystallization, the orientation of the pockets is parallel to the regional S1 foliation (N38 $\left.20.376^{\prime} / \mathrm{E} 113^{\circ} 36.953^{\prime}\right)$. (B) Fractured feldspar healed by quartz and feldspar aggregate that is continuous with matrix grains suggesting that the deformation occurred while the rock was partly crystallized but melt still remained. (C) Lobe-shaped myrmekite developed along grain boundary margins of cross-hatched microclines. 


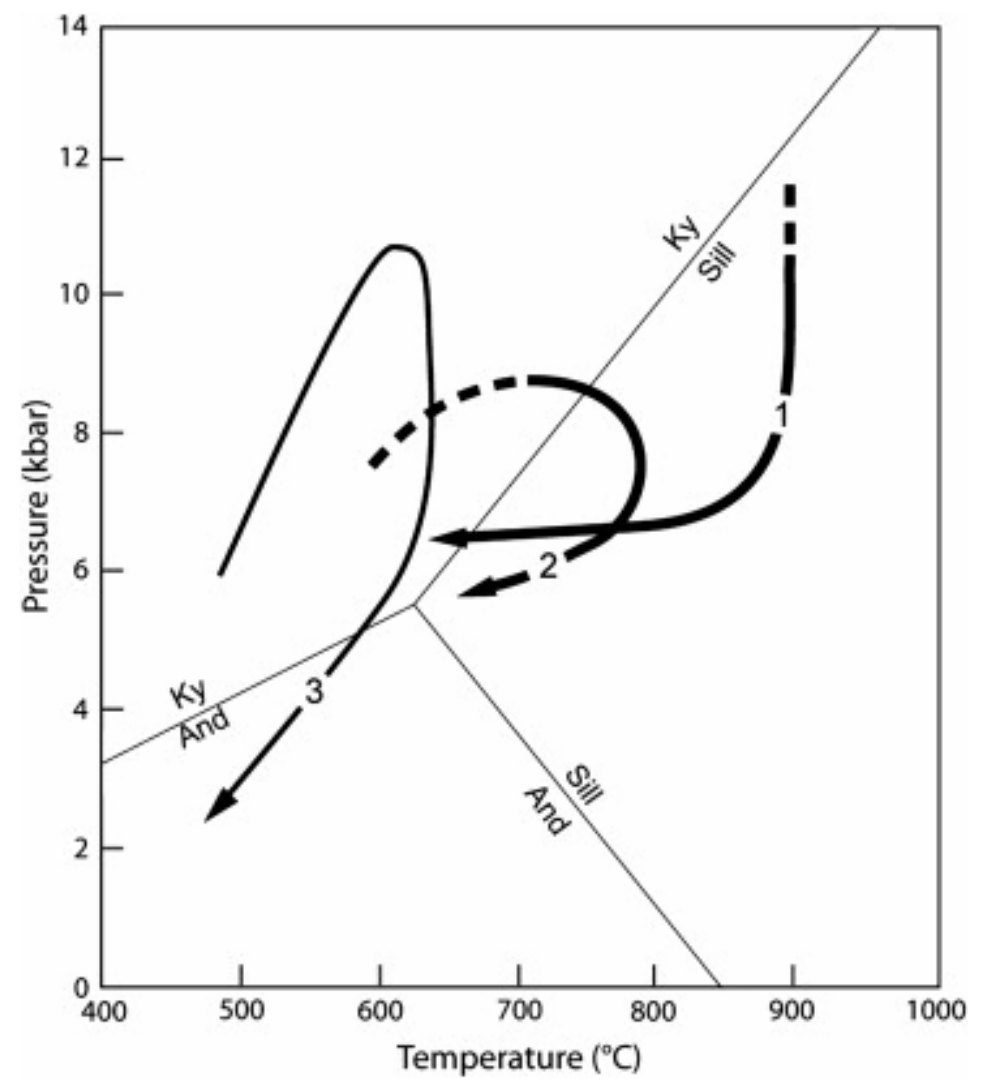

Fig. 13. $P-T$ diagram showing the different metamorphic $P-T-t$ paths inferred from rocks of the Fuping massif (1 and 2), and the Wutaishan (3) for comparison (modified after Zhao et al., 2000b). 1, $P-T-t$ path estimated from enclaves of mafic granulites within the Fuping migmatite (Zhao et al., 2000b); 2, $P-T-t$ path estimated from the pelitic gneisses of the Wanzi supracrustal assemblage (Liu and Liang, 1997); 3, $P-T-t$ path estimated from amphibolites from the OVU, in the Wutaishan massif, above the hangingwall of the Longquanguan Thrust (Zhao et al., 1999). The $\mathrm{Al}_{2} \mathrm{SiO}_{5}$ diagram is from Holdaway and Murkhopadhyay (1993). 
A



C

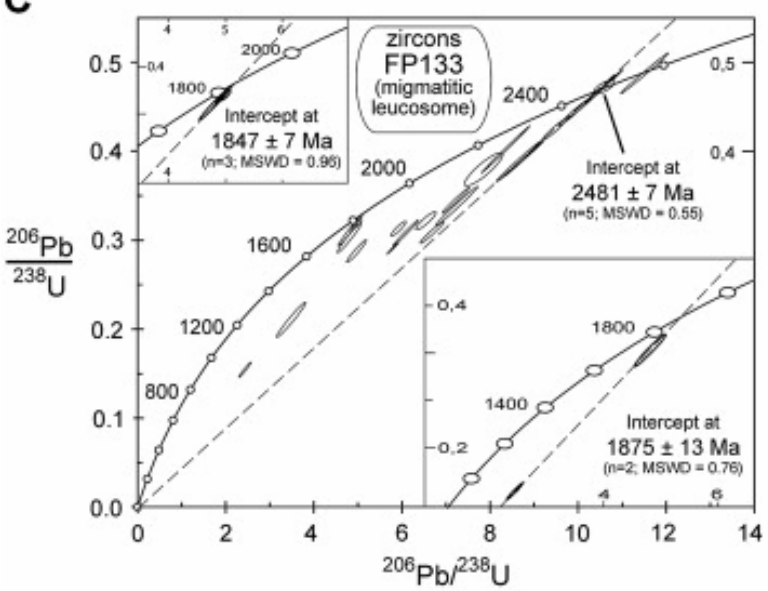

E

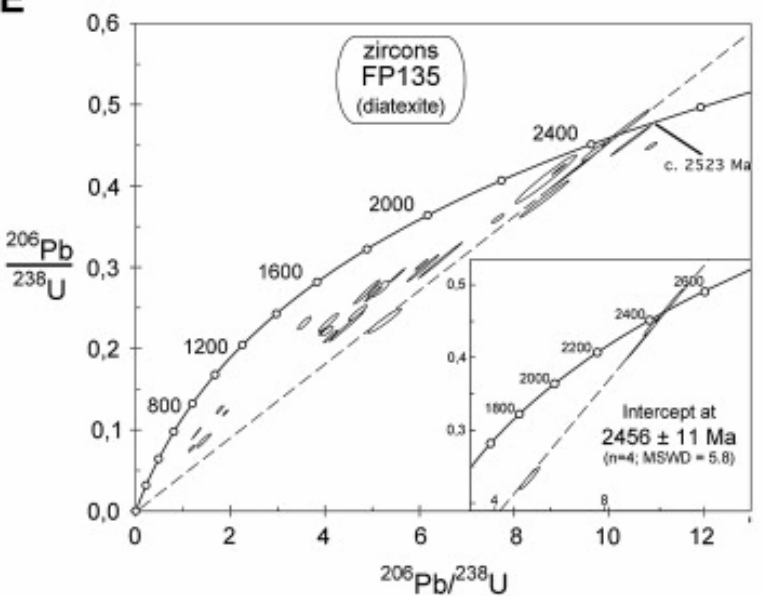

B

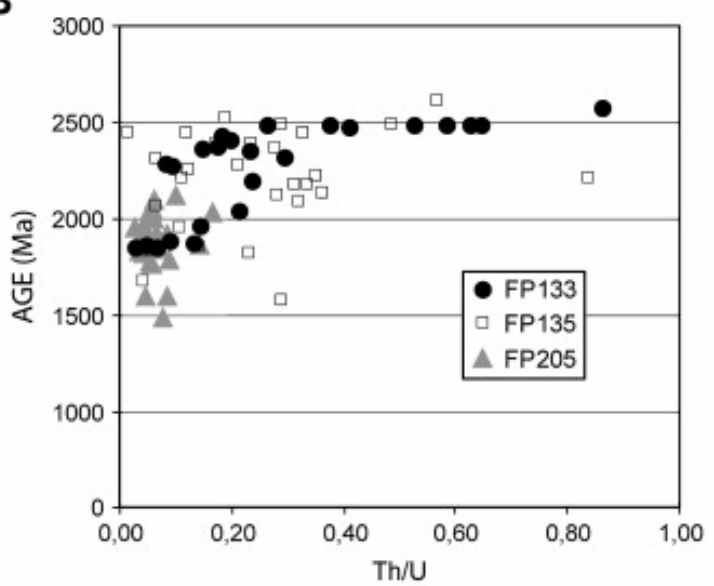

D

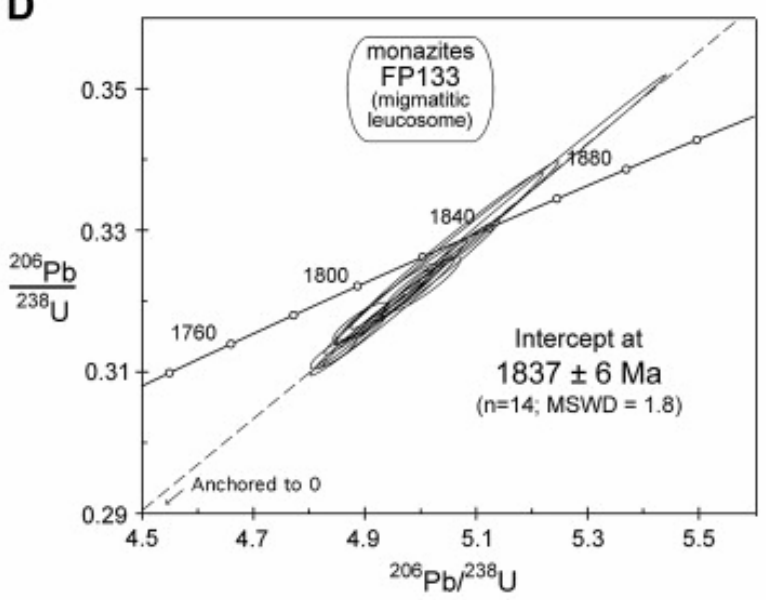

$\mathbf{F}$

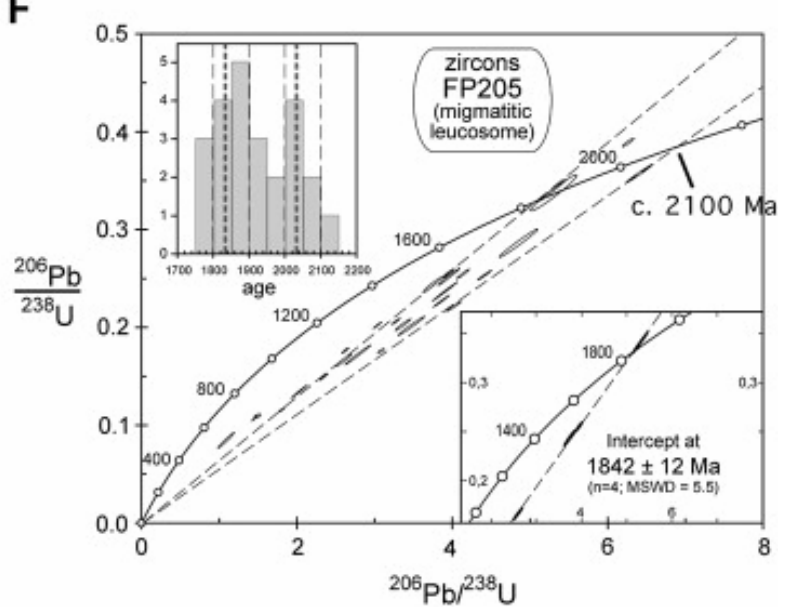

Fig. 14. (A) ${ }^{40} \mathrm{Ar}-{ }^{39} \mathrm{Ar}$ muscovite age spectra for sample FP154 from the Pingshan fault. (B) U-Pb age (Ma) vs Th-U diagram for LA-ICP-MS zircon analyses from samples FP133, FP135 and FP205. (C, D, E and F) LA-ICP-MS U-Pb concordia diagrams for samples FP133, FP135 and FP205. 


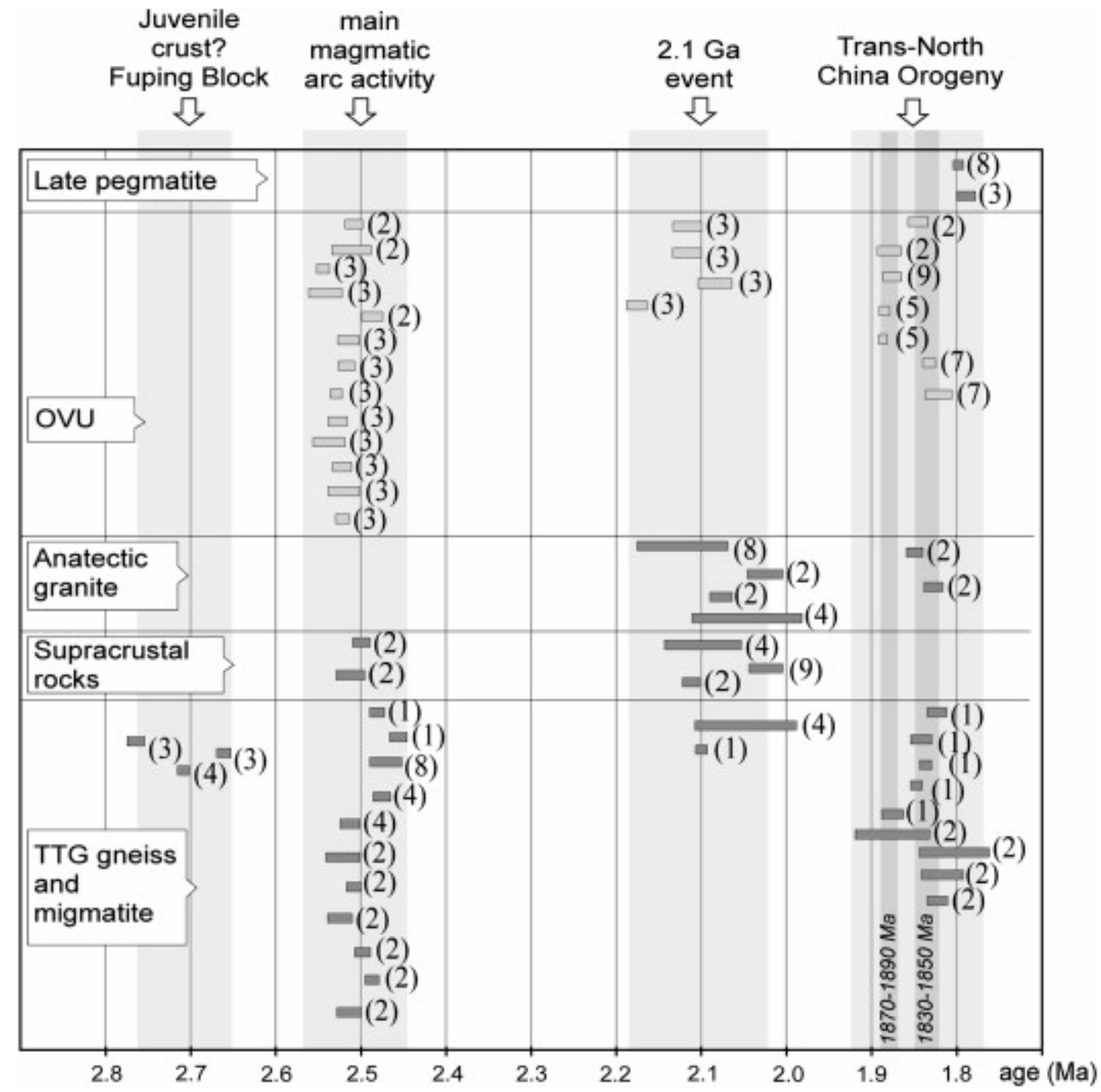

Fig. 15. Synoptic diagram showing ages obtained in the Fuping Massif (dark grey) in complement with those obtained in the OVU from Wutaishan (pale grey): 1, this study; 2 , Zhao et al., 2002 (SHRIMP U-Pb zircon); 3, [Wilde et al., 1998], [Wilde et al., 2004] and [Wilde et al., 2005] (SHRIMP U-Pb zircon); 4, Guan et al., 2002 (SHRIMP U-Pb zircon); 5, Trap et al., 2007 (U-Th-Pb EPMA dating monazite); 6, Faure et al., 2007 (U-Th-Pb EPMA dating on monazite); 7, Liu et al., 2006 (U-Th-Pb EPMA dating on monazite); 8, [Liu et al., 1985] and [Liu et al., 2000] (SHRIMP U-Pb zircon); 9, Zhao et al., 2006 (U-Th-Pb EPMA dating on monazite). 